NBER WORKING PAPER SERIES

\title{
FISCAL MULTIPLIERS IN RECESSION AND EXPANSION
}

\author{
Alan J. Auerbach \\ Yuriy Gorodnichenko \\ Working Paper 17447 \\ http://www.nber.org/papers/w17447 \\ NATIONAL BUREAU OF ECONOMIC RESEARCH \\ 1050 Massachusetts Avenue \\ Cambridge, MA 02138 \\ September 2011
}

This paper is being prepared for the NBER conference, Fiscal Policy after the Financial Crisis, to be held in Milan, December, 2011. We thank participants in the July, 2011 pre-conference for comments on an earlier draft. The views expressed herein are those of the authors and do not necessarily reflect the views of the National Bureau of Economic Research.,

NBER working papers are circulated for discussion and comment purposes. They have not been peerreviewed or been subject to the review by the NBER Board of Directors that accompanies official NBER publications.

(C) 2011 by Alan J. Auerbach and Yuriy Gorodnichenko. All rights reserved. Short sections of text, not to exceed two paragraphs, may be quoted without explicit permission provided that full credit, including ( $)$ notice, is given to the source. 
Fiscal Multipliers in Recession and Expansion

Alan J. Auerbach and Yuriy Gorodnichenko

NBER Working Paper No. 17447

September 2011

JEL No. E32,E62

\begin{abstract}
$\underline{\text { ABSTRACT }}$
In this paper, we estimate government purchase multipliers for a large number of OECD countries, allowing these multipliers to vary smoothly according to the state of the economy and using real-time forecast data to purge policy innovations of their predictable components. We adapt our previous methodology (Auerbach and Gorodnichenko, 2011) to use direct projections rather than the SVAR approach to estimate multipliers, to economize on degrees of freedom and to relax the assumptions on impulse response functions imposed by the SVAR method. Our findings confirm those of our earlier paper. In particular, GDP multipliers of government purchases are larger in recession, and controlling for real-time predictions of government purchases tends to increase the estimated multipliers of government purchases in recession. We also consider the responses of other key macroeconomic variables and find that these responses generally vary over the cycle as well, in a pattern consistent with the varying impact on GDP.
\end{abstract}

\author{
Alan J. Auerbach \\ Department of Economics \\ 508-1 Evans Hall, \#3880 \\ University of California, Berkeley \\ Berkeley, CA 94720-3880 \\ and NBER \\ auerbach@econ.berkeley.edu \\ Yuriy Gorodnichenko \\ Department of Economics \\ 508-1 Evans Hall \#3880 \\ University of California, Berkeley \\ Berkeley, CA 94720-3880 \\ and NBER \\ ygorodni@econ.berkeley.edu
}




\section{Introduction}

A key issue coming out of recent economic events is the size of fiscal multipliers when the economy is in recession. In a recent paper (Auerbach and Gorodnichenko, 2011), we extended the standard Structural Vector Autoregression (SVAR) methodology in three ways to shed light on this issue. First, using regime-switching models, we estimated effects of fiscal policies that can vary over the business cycle, finding large differences in the size of spending multipliers in recessions and expansions with fiscal policy being considerably more effective in recessions than in expansions. Second, we estimated multipliers for more disaggregate spending variables which behave differently in relation to aggregate fiscal policy shocks, with military spending having the largest multiplier. Third, we showed that controlling for real-time predictions of fiscal variables tends to increase the size of the multipliers in recessions.

In this paper, we extend our previous analysis in three important ways. First, we estimate multipliers for a large number of OECD countries, rather than just for the United States, again allowing for state dependence and controlling for information provided by predictions. Second, we adapt our previous methodology to use direct projections rather than the SVAR approach to estimate multipliers, to economize on degrees of freedom and to relax the assumptions on impulse response functions imposed by the SVAR method. Third, we estimate responses not only of output but also of other macroeconomic aggregates. Our findings confirm those of our earlier paper. In particular, multipliers of government purchases are larger in recession, and controlling for real-time predictions of government purchases tends to increase the estimated multipliers of government spending in recession. 


\section{Methodology}

Before developing our current approach, we review the one taken in our earlier paper. We developed what we referred to there as a smooth transition vector autoregression (STVAR), based on the smooth transition autoregressive (STAR) models developed in Granger and Teravistra (1993); one important difference in our approach is that we allow not only differential dynamic responses but also differential contemporaneous responses to structural shocks. Our basic specification, without controlling for real-time predictions, was:

$$
\begin{aligned}
& \mathbf{X}_{t}=\left(1-F\left(z_{t-1}\right)\right) \boldsymbol{\Pi}_{E}(L) \mathbf{X}_{t-1}+F\left(z_{t-1}\right) \boldsymbol{\Pi}_{R}(L) \mathbf{X}_{t-1}+\mathbf{u}_{t} \\
& \mathbf{u}_{t} \sim N\left(\mathbf{0}, \boldsymbol{\Omega}_{t}\right) \\
& \boldsymbol{\Omega}_{t}=\boldsymbol{\Omega}_{E}\left(1-F\left(z_{t-1}\right)\right)+\boldsymbol{\Omega}_{R} F\left(z_{t-1}\right) \\
& F\left(z_{t}\right)=\frac{\exp \left(-\gamma z_{t}\right)}{1+\exp \left(-\gamma z_{t}\right)}, \quad \gamma>0
\end{aligned}
$$

where $\mathbf{X}_{t}=\left[\begin{array}{lll}G_{t} & T_{t} & Y_{t}\end{array}\right]^{\prime}$ is a vector of the logarithms of real government purchases $\left(G_{t}\right)$, taxes net of transfers $\left(T_{t}\right)$, and real Gross Domestic Product (GDP, $\left.Y_{t}\right)$, observed at a quarterly frequency; $z$ is an indicator of the state of the economy, normalized to have zero mean and unit variance; and the matrices $\boldsymbol{\Pi}_{i}(L)$ and $\boldsymbol{\Omega}_{i}(L)$ representing the VAR coefficients and variance-covariance matrix of disturbances in two regimes, recession $(i=R)$ and expansion $(i=E)$. The weights assigned to each regime for a given observation weighting function $F(\cdot)$ vary between 0 and 1 according to the contemporaneous state of the economy, $z$, which we took to be a moving average of real GDP growth.

In our earlier paper, we considered a variety of approaches to extend this basic model to take account of real-time information regarding expectations of fiscal variables and GDP, available from a variety of sources. One of these approaches, which we will use in this paper, was to include a direct measure of the unanticipated component of government purchases, equal to the difference between actual purchases $G_{t}$ and the forecast of this variable one period earlier, 
$G_{t \mid t-1}$. This forecast is typically taken from a survey of professional forecasters, projections prepared by government or international agencies (e.g., Greenbook forecasts prepared by the Federal Reserve staff) or other credible sources (e.g., financial markets). Specifically, we estimated the SVAR for $\widehat{\mathbf{X}}_{t}=\left[\begin{array}{llll}F E_{t}^{G} & G_{t} & T_{t} & Y_{t}\end{array}\right]^{\prime}$ where $F E_{t}^{G}$ is the forecast error computed as the difference between forecast series and actual, first-release series of the government spending growth rate. ${ }^{1}$ By stacking $F E_{t}^{G}$ first in the SVAR, we could then estimate directly from the SVAR coefficients the multipliers for unanticipated government purchases. ${ }^{2}$

In contrast to Auerbach and Gorodnichenko (2011) focusing only on the U.S. macroeconomic time series, in this paper we use data on multiple countries available from the OECD, for which consistent measures of actual and forecast values are available only at a semiannual frequency, rather than quarterly. This lower frequency of observations, in conjunction with the availability of data starting at a later date than our data for the United States, substantially reduces the number of observations we have for any particular country. For such short time series, our original approach, which involves highly nonlinear estimation of a large number of parameters, would be very challenging. Therefore, we modify our approach in two ways. First, we use panel estimation, allowing intercepts to vary by country but constraining other coefficients to be the same. Second, rather than estimating the entire system of equations in the STVAR and using these to estimate impulse response functions (IRFs), we estimate the IRFs directly by projecting a variable of interest on lags of variables entering the VAR or more generally variables capturing information available in a given time period. This single-equation approach has been advocated by Jorda (2005), Stock and Watson (2007), and others as a flexible alternative which does not impose dynamic restrictions implicitly embedded in VARs and which

\footnotetext{
${ }^{1}$ We compare forecasts to contemporaneous measures to take account of subsequent data revisions.

${ }^{2}$ Because this SVAR includes a forecast of a variable in addition to standard macroeconomic variables, this approach is also known as the expectations-augmented VAR, or EVAR.
} 
can conveniently accommodate nonlinearities in the response function. For example, when we use GDP as the dependent variable, the response of $Y$ at the horizon $h$ is estimated from the following regression:

$$
\begin{aligned}
Y_{i, t+h}= & \alpha_{i, h}+F\left(z_{i t}\right) \boldsymbol{\Pi}_{R, h}(L) Y_{i, t-1}+\left(1-F\left(z_{i t}\right)\right) \boldsymbol{\Pi}_{E, h}(L) Y_{i, t-1} \\
& +F\left(z_{i t}\right) \boldsymbol{\Psi}_{R, h}(L) G_{i, t-1}+\left(1-F\left(z_{i t}\right)\right) \boldsymbol{\Psi}_{E, h}(L) G_{i, t-1} \\
& +F\left(z_{i t}\right) \boldsymbol{\Phi}_{R, h} F E_{i t}^{G}+\left(1-F\left(z_{i t}\right)\right) \boldsymbol{\Phi}_{E, h} F E_{i t}^{G}+u_{i t},
\end{aligned}
$$

with $F\left(z_{i t}\right)=\frac{\exp \left(-\gamma z_{i t}\right)}{1+\exp \left(-\gamma z_{i t}\right)}, \quad \gamma>0$,

where $i$ and $t$ index countries and time, $\alpha_{i}$ is the country fixed effect, $F(\cdot)$ is the transition function, $z_{i t}$ is a variable measuring the state of the business cycle, $F E_{i t}^{G}$ is the forecast error for the growth rate of government spending in the forecasts prepared by professional forecasters at time $t-1$ for period $t$. Note that all coefficients vary with the horizon $h$; that is, a separate regression is estimated for each horizon.

We interpret $F E_{i t}^{G}$ as the surprise government spending shock. This treatment of what constitutes a shock is consistent with Ramey (2011) and Auerbach and Gorodnichenko (2011) where changes in spending are projected on professional forecasts to construct a series on unanticipated innovations in spending. Observe that by controlling for information contained in lags of $Y$ and $G$ we purify $F E_{i t}^{G}$ of any predictable component that would have been eliminated had the professional forecaster run a VAR. The fact that we include government spending shock $F E_{i t}^{G}$ dated by time is consistent with the recursive ordering of government spending first in the VARs.

In the STVAR or standard VAR analysis of how government spending shocks affect the economy, the impulse response is constructed in two steps. First, the contemporaneous responses are derived from a Cholesky decomposition of $\boldsymbol{\Omega}_{t}$ in equation (3) with government spending ordered first. In Auerbach and Gorodnichenko (2011) we allowed contemporaneous responses to vary since $\boldsymbol{\Omega}_{t}$ can change over the business cycle. Second, the propagation of the 
responses over time is obtained by using estimated coefficients in the lag polynomials such as $\boldsymbol{\Pi}_{R}(L)$ and $\boldsymbol{\Pi}_{E}(L)$ in equation (1) applied to the contemporaneous responses from the first step. The direct projection method effectively combines these two steps into one.

Note that the lag polynomials $\left\{\boldsymbol{\Pi}_{R, h}(L), \boldsymbol{\Psi}_{R, h}(L), \boldsymbol{\Pi}_{E, h}(L), \boldsymbol{\Psi}_{E, h}(L)\right\}$ in equation (5) are used to control for the history of shocks rather than to compute the dynamics. The dynamics are constructed by varying the horizon $h$ of the dependent variable so that we can directly read the impulse responses off estimated $\left\{\boldsymbol{\Phi}_{E, h}\right\}_{h=0}^{H}$ for expansions and $\left\{\boldsymbol{\Phi}_{R, h}\right\}_{h=0}^{H}$ for recessions. For horizon $h=0$, the impulse response constructed with this approach recovers the response constructed with a STVAR where $F E_{i t}^{G}$ is ordered first. At longer horizons, however, there is potentially a difference between the approaches. To simplify the argument, suppose that the STVAR has just one lag $\boldsymbol{\Pi}_{R}$ in $\boldsymbol{\Pi}_{R}(L)$. Then this STVAR imposes that dynamics at short and long horizons are described by the same matrix $\boldsymbol{\Pi}_{R}$ (or more generally with a handful of matrixes like $\boldsymbol{\Pi}_{R}$ ) while direct projections do not impose such a restriction.

One can think of the direction projection approach as constructing a moving average representation of a series: the lag polynomial terms control for initial conditions while $\left\{\boldsymbol{\Phi}_{E, h}\right\}_{h=0}^{H}$ and $\left\{\boldsymbol{\Phi}_{R, h}\right\}_{h=0}^{H}$ describe the behavior of the system in response to a structural, serially uncorrelated shock. Indeed, if we abstract from variation in initial conditions at time $t$, we effectively regress a variable of interest at time $t+h$ on a shock in a given regime at time $t$ and thus we obtain an average response of the variable of interest $h$ periods after the shock, which is precisely the definition of an impulse response.

This estimation method has several advantages over our earlier approach. First, it involves only linear estimation, if one fixes (as we have throughout our work) the parameter $\gamma$ in expression (4). Second, it obviates the need to estimate the equations for dependent variables other than the variable of interest (e.g., GDP) and thus we can significantly economize on the 
number of estimated parameters. Third, it does not constrain the shape of the IRF, rather than imposing the pattern generated by the SVAR. (Under the maintained assumption that the SVAR is correctly specified, the patterns should be the same.) Fourth, the error term in equation (5) is likely to be correlated across countries. This correlation would be particularly hard to handle in the context of nonlinear STVARs but is easy to address in linear estimation by using e.g. Driscoll-Kraay (1998) standard errors or clustering standard errors by time period. Fifth, we can use specification (5) to construct impulse responses for any macroeconomic variable of interest as we are not constrained by the VAR's curse of dimensionality. Finally, because the set of regressors in (5) does not vary with the horizon $h$, the impulse response incorporates the average transitions of the economy from one state to another. In other words, we do not have to separately model how $z$ changes over time. If government spending shocks systematically affect the state of the economy (e.g., an unanticipated increase in government spending during a recession pushes the economy into expansion and thus $z$ changes from a negative value to a positive value), this systematic effect will be absorbed into estimated $\left\{\boldsymbol{\Phi}_{E, h}\right\}_{h=0}^{H}$ and $\left\{\boldsymbol{\Phi}_{R, h}\right\}_{h=0}^{H}$ (e.g., $\boldsymbol{\Phi}_{R, h}$ will be lower if the response of output to government spending shocks is smaller during expansions than during recessions). In contrast, using the system in (1) requires that we explicitly model the dynamics of $z$.

Similar to our earlier paper, $z_{i t}$ is based on the (standardized) deviation of the output growth rate (moving average over 1.5 years) from the trend. However, in contrast to the earlier paper, we allow the trend to be time-varying because several counties exhibit low frequency variations in the growth rates of output. Specifically, we extract the trend using the HodrickPrescott filter with a very high smoothing parameter $\lambda=10,000$ so that the trend is very smooth. Because identification of the curvature in the transition function $F(\cdot)$ is based on highly nonlinear moments and thus is potentially sensitive to a handful of unusual observations, we 
follow our earlier approach and calibrate $\gamma=1.5$ so that a typical economy spends about 20 percent of the time in a recessionary regime, which is consistent the fraction of recessionary periods in the United States.

The linear analogue of specification (5) is given by

$$
Y_{i, t+h}=\alpha_{i, h}+\boldsymbol{\Pi}_{L i n, h}(L) Y_{i, t-1}+\boldsymbol{\Psi}_{L i n, h}(L) G_{i, t-1}+\boldsymbol{\Phi}_{L i n, h} F E_{i t}^{G}+u_{i t}
$$

where the response of $Y$ is constrained to be the same for all values of $z_{i t}$; i.e., $\boldsymbol{\Pi}_{L i n, h}(L)=$ $\boldsymbol{\Pi}_{E, h}(L)=\boldsymbol{\Pi}_{R, h}(L), \boldsymbol{\Psi}_{L i n, h}(L)=\boldsymbol{\Psi}_{E, h}(L)=\boldsymbol{\Psi}_{R, h}(L)$, and $\boldsymbol{\Phi}_{L i n, h}=\boldsymbol{\Phi}_{E, h}=\boldsymbol{\Phi}_{R, h}$ for all $L$ and $h$.

\section{Data}

The macroeconomic series we use in our analyses come from the OECD’s Statistics and Projections database. There are several benefits of using these data. First, macroeconomic series and forecasts for these series are prepared using a unified methodology so that series are comparable across countries. Second, the OECD prepares semiannual forecasts for key macroeconomic variables such as GDP and government spending in June and December of each year. The OECD’s forecasts are available for a broad array of variables. Third, these forecasts have "reality checks," as the OECD exploits its local presence in the member countries and holds extensive discussions on the projections and related analyses with local government experts and policy makers. Thus, the OECD’s forecasts incorporate a great deal of local knowledge and information about future policy changes. Fourth, in recent assessments of the OECD’s forecasts, Vogel (2007) and Lenain (2002) report that these forecasts have a number of desirable properties and perform at par with the forecasts prepared by the private sector. More information on these forecasts is available at the OECD's website. ${ }^{3}$

\footnotetext{
${ }^{3}$ http://www.oecd.org/faq/0,3433,en_2649_33733_1798284_1_1_1_1,00.html
} 
The OECD’s forecasts are consistently available since 1985 for “old” members of the OECD (e.g., the United States) and since the mid-1990s for newer members (e.g., Poland). The downside of using the OECD projections is that, for most of the available sample, they are available only at the semiannual frequency rather than the quarterly frequency more commonly used in the SVAR literature.

Consistent with the OECD definitions and the previous literature on fiscal multipliers, our government spending series is the sum of real public consumption expenditure and real government gross capital formation. That is, it does not include imputed rent on the government capital stock, as is now the convention in the U.S. national income accounts. In addition to the standard real GDP series, we will examine responses of other key macroeconomic variables to government spending shocks. First, we document responses of other components of GDP: real private consumption, real private gross capital formation, real exports and imports. Second, we investigate the behavior of the variables describing the labor market: total employment in the economy, employment in the private sector, the unemployment rate, and the real compensation rate in the private sector. This last series is our measure of real wages. Finally, we explore how prices, measured by the consumer price index (CPI) and the GDP deflator, respond to government spending shocks. All variables except the unemployment rate enter specification (5) in logs.

\section{Results}

\section{A. Impulse responses in a VAR and direct projections method}

As a first pass through the data, we examine how our approach of direct projections compares with the more conventional approach of using VARs to construct impulse responses. Figure 1 contrasts the impulse response of output to a one-percent increase in government spending in a linear bivariate VAR — which includes real GDP and real government spending as endogenous 
variables and country fixed effects with slopes assumed to be the same across countries—with the impulse response of output to the same shock in government spending in the specification given by (5'), which is restricted to have the same responses and dynamics in recessions and expansions. Note that, since the linear VAR uses a Cholesky decomposition, the contemporaneous responses have to be the same in these two approaches. However, even when we extend the horizons, the responses are remarkably similar across approaches and thus we can be more confident that our subsequent results are not driven by using an alternative approach to construct impulse responses.

\section{B. Predictability of VAR shocks}

A key assumption in the construction of fiscal multipliers is that shocks to government spending are not forecastable. VARs try to ensure unforecastability of shocks by including sufficiently many lags of endogenous variables so that the error term is orthogonal to information contained in the past values of macroeconomic variables. However, as has been discussed extensively in the literature (see e.g. Ramey 2011), many changes in fiscal variables are anticipated and lagged values of the few variables included in the VAR may fail to capture these anticipated future changes.

To assess the extent to which VAR shocks are forecastable, we perform the following exercise. First, we project growth rates of government spending predicted by the OECD forecasts on the lags of endogenous variables in the VAR to remove the component of government spending growth that is predictable on the basis of information contained in the VAR. Second, we compute the error term in the government spending equation in the VAR with the same number of lags of endogenous variables - the standard VAR shocks. Third, we check the correlation between these two series, which should be zero if the OECD forecasts do not have systematically better information than is contained in the lagged variables of the VAR. In 
fact, we find (Figure 2) that the VAR shocks are predicted by professional forecasters to a significant degree: the correlation between the two series is 0.36 . In other words, a considerable part of the VAR shocks to government spending is anticipated by the OECD forecasts. This suggests that estimates of impulse responses in the conventional VAR approach may be seriously biased, as the responses to anticipated and unanticipated shocks, in theory, can be radically different.

To minimize the contamination of government spending shocks with predictable changes, we will project the forecast errors of the OECD government spending forecasts on the lags of output (or any other endogenous variable of interest, e.g., private consumption) and government spending and take the residual from this projection as a government spending shock, i.e., $F E_{i t}^{G}$ in specification (5). Figure 3 presents time series of constructed government spending shocks for selected countries.

\section{State-dependent impulse responses}

Figure 4 presents impulses responses of key macroeconomic variables to an unanticipated one percent increase in government spending. Each panel in this figure has two subpanels showing responses (black, thick line) in a recessionary regime ( $z$ has a large negative value; the response is given by $\left\{\widehat{\boldsymbol{\Phi}}_{R, h}\right\}_{h=0}^{H}$ ) and an expansionary regime ( $z$ has a large positive value; the response is given by $\left.\left\{\widehat{\boldsymbol{\Phi}}_{E, h}\right\}_{h=0}^{H}\right)$. Because the data are semiannual, the time horizons are in half-year increments. The thin, dashed lines indicate the $90 \%$ confidence bands which are based on Driscoll-Kraay (1998) standard errors that allow arbitrary correlations of the error term in specification (5) across countries and time. As a point of comparison, each subpanel also reports the response in the linear model (5’) (thin red line) and associated 90\% confidence bands (shaded region) which are also based on Driscoll-Kraay (1998) standard errors. ${ }^{4}$

\footnotetext{
${ }^{4}$ The responses are normalized so that the government spending response to a shock in $F E_{i t}^{G}$ is equal to unity.
} 
The responses of output (Panel A) are remarkably different across regimes and models. In the linear model, only the contemporaneous response is positive and marginally statistically significant. For the next two periods, the response is positive but not statistically different from zero and then the point estimates of the response turn negative although we cannot reject the null that these responses are zero. In contrast, the response of output in the recessionary regime is robustly positive up to two years. If we use the sample-period U.S. average ratio of government purchases to output $(\approx 5.12)$ to convert percentage changes into dollar changes, the maximum size of the government spending multiplier is about 3.5 with the $90 \%$ confidence interval being $(0.6,6.3)$. The average government spending multiplier over three years is about $\$ 2.3$. The response of output in the expansionary regime is much weaker, in fact negative at some horizons, but generally we cannot reject the null that the response is zero for most horizons. This result is consistent with our earlier work for the United States where we estimated the spending multiplier to be approximately zero in expansions and about 1.5-2.0 in recessions. This finding is also consistent with the estimates reported in the nascent literature that explores cyclical variation of fiscal multipliers. For example, Bachmann and Sims (2011) report that the spending multiplier is approximately zero in expansions and approximately 3 in recessions. Using state-level variation in government spending, Shoag (2011) finds that the multiplier is approximately 3.0-3.5 when labor markets have a slack, which could interpreted as a recessionary regime, and only approximately 1.5 when there is no slack, which could interpreted as an expansionary regime. Finally, government spending shocks in the linear model have some effect on output. Consistent with Blanchard and Perotti (2002) and the literature that followed, the multiplier is about one if we continue to use the U.S. average ratio of government purchases to output ratio as above. It is clear, however, that the linear model can considerably underestimate the stimulating power of government spending in recessions and overstate it in expansions. 
One may be concerned that we find a strong response of output to government spending shocks in recessions because these shocks systematically occur in periods when an economy starts to recover so that one can find a positive correlation between output growth and government spending shocks. Note that we use professional forecasts to purge predictable movements in government spending. Thus, if there is any systematic pattern in how government spending reacts to the state of the economy, we remove this correlation. We also find no statistically or economically significant correlation between our government spending shocks and measures of the state of a business cycle (e.g., $F\left(z_{i t}\right)$ ) or changes in that state (e.g., $\Delta F\left(z_{i t}\right)$ ). In other words, when the economy is in a recession or is starting to move into an expansion, a contractionary government spending shock is as probable as an expansionary government spending shock. Therefore, it is unlikely that our results are driven by a particular timing of government spending shocks.

The first rows of Tables 1 and 2 present estimates of the output response to government spending shocks over the three year horizon. The tables report two statistics: the mean response computed as $\sum_{h=0}^{H} Y_{h} / \sum_{h=0}^{H} G_{h}$ and the maximum response computed as $\max _{h=0, . ., H} Y_{h}$ with $H=5$ which corresponds to three years. The last rows of the tables show the estimates of the output response when we use VAR residuals rather than forecast errors of professional forecasts as a measure of government spending shocks. Although the difference between the estimates in the first and last rows is not statistically different from zero, the point estimates based on VAR residuals are consistently lower by $0.1-0.2$ (or about 50 cents to a dollar if we use the ratio of output to government spending in the U.S.) in recessionary periods than the point estimates based on the forecast errors of professional forecasters. Thus, controlling for predictable movements in government spending raises the size of the output responses, which is consistent 
with the theoretical implications of how output should respond to anticipated and unanticipated changes in government spending.

These differential responses of output naturally raise the questions about the channels of amplification and propagation of government spending shocks through the economies. To get a sense of the basic mechanisms behind these responses, we examine in Tables 1 and 2 and Figure 4, which corresponds to Table 1, the responses of various macroeconomic variables to government spending shocks.

Panel B shows that private consumption appears to be crowded out in expansions and to be stimulated in recessions by government spending shocks. If we take the ratio of government spending to private consumption for the U.S. $(\approx 3.5)$, a dollar increase in government spending in recessions can increase consumption up to $\$ 2.8$ with a 90 percent confidence interval of (1.4, 4.2). Although some may consider this multiplier as too large to be plausible, note that it applies to a very deep recession and that the average response over three years is about $\$ 2$. Also observe that the linear model predicts that the maximum response of consumption to a dollar increase in government spending would be approximately $\$ 1$, which is not small economically but in statistical terms is marginally significantly different from zero. Although we do not have data to explore further the sources of these consumption multipliers, Bachmann and Sims (2011) argue that an important ingredient for stimulating consumption in recessions is the response of consumer confidence to government spending shocks. Bachmann and Sims note that government spending shocks may have pure sentiment effects (i.e., one can think of “animal spirits” shifted by changes in government spending) and news effects when changes in government spending provide signals about future changes in output and productivity. In the U.S. context, Bachmann and Sims find that it is the latter effect that stimulates confidence and hence consumption. 
The countercyclical pattern of crowding-out and stimulatory effects of government spending are particularly apparent in the responses of private investment (Panel C). Over three years, a dollar increase in government spending increases investment in recessions by approximately $\$ 1.5$ and decreases investment in expansions by approximately $\$ 1.4$ if we use the ratio of private investment to government spending in the United States $(\approx 0.8)$. In contrast, the linear model would predict that investment does not respond to government spending shocks. Thus, imposing the same responses in recessions and expansions can mask a great deal of heterogeneity in responses over the business cycle.

Panel D, E and F show the responses of total employment, employment in the private sector, and the unemployment rate. In the recessionary regime, increased government spending leads to more total employment. This increase in employment comes to a large extent from the increase in the private sector employment. For example, after 2.5 years, total employment increases by 0.5 percent while the private employment increases by 0.9 percent in responses to a one percent increase in government spending given that the economy is in a recession. Consistent with the employment responses, the unemployment rate shrinks after a government spending shock in a recession. On the other hand, the response of employment (or the unemployment rate) to a government spending shock in an expansion is anemic at best: it is generally close to zero and not statistically different from zero.

To have a better sense of what the percentage changes mean in terms of jobs, we can use the ratio of private employment to real government spending for the U.S. $(\approx 49$ thousands/billion) to find that a one billion dollar increase in government spending creates approximately 44 thousand jobs; the 90 percent confidence interval is fairly wide and ranges from 2 to 88 thousand jobs per a billion dollar increase in government spending. One can also interpret this magnitude as stating that it takes about 23 thousand dollars to create a job in a 
recession. Although it is hard to come by a comparable estimate of employment multipliers during recessions in the literature, a few recent studies use the state- or county-level variation in government spending due to fiscal stimulus in the U.S. during the 2009-2010 period to estimate how many jobs were saved or created due to the fiscal stimulus. For example, Wilson (2010) reports that a billion-dollar increase in government spending raises employment by 25 thousand jobs with standard error of 9.0 thousand jobs, i.e., an incremental job costs 39.2 thousand dollars with the 90 percent confidence interval ranging between 25 and 96 thousand dollars. ChodorowReich et al. (2011) estimate that $\$ 100,000$ increase in spending increases employment by about 3.5 jobs with standard error of 1.7 jobs or, alternatively, an additional job costs approximately 28 thousand dollars. Thus, our estimates of employment multipliers in a recession are broadly in line with alternative estimates in this literature. ${ }^{5}$

We can get further insight into the workings of the labor market by examining the responses of real wages in expansions and recessions (Panel G). We find that real wages remain largely unchanged in response to government spending shocks when the economy is in a recession. In contrast, government spending shocks appear to spur an increase in real wages in the expansionary regime. These results taken together with the responses of employment suggest that government spending shocks are probably absorbed into higher wages in expansions and into higher employment in recessions, which is consistent with the differences in our output multipliers across regimes.

Panels $\mathrm{H}$ and I show the responses of real exports and real imports. By and large, we find only weak reactions of these variables to government spending shocks. Only the contemporaneous response of exports (negative) and imports (positive) are marginally significant

\footnotetext{
${ }^{5}$ It should be kept in mind that these other recent estimates are based on cross-section variation and therefore cannot take into account the possible positive or negative spillovers that spending in one state might have on employment changes in another state.
} 
in the recessionary regime. The pattern of the contemporaneous responses is consistent with short-term appreciation of the domestic currency, which could in turn be triggered by an increase in interest rates caused by a strengthening economy and/or the response of the monetary authorities to counteract spending shocks.

Finally, Panels $\mathrm{J}$ and $\mathrm{K}$ show the response of the price level as measured by the consumer price index (CPI) and GDP deflator respectively. Generally, government spending shocks lead to inflationary contemporaneous responses in expansions and deflationary responses in recessions. At the longer horizons we cannot reject the null that the response of the price level is zero in either of the regimes. These responses are largely consistent with the idea that prices may be relatively inflexible in the short run and most of the adjustment occurs via quantities.

\section{Robustness and sensitivity analysis}

In the baseline formulation of the empirical model, we use a moving average of the output growth rate to measure the state of the business cycle in a given economy. The key advantage of using this variable is that the growth rate of output is a coincident indicator. However, Keynesian theories rely on the notion of slack as a stock variable (e.g., how many workers are unemployed) rather than a flow variable (e.g., output growth rate or how many workers are hired or fired). Since the moving average is computed over 1.5 years and thus it is cumulative to some extent, one can interpret it as capturing output gap and thus a degree of slack in the economy. Perhaps more importantly, commonly used stock variables such as unemployment rate or CBO's potential output measure typically lag the business cycle; thus these variables may provide a wrong sense of where an economy happens to be. Indeed, a high unemployment rate can extend well into a strong expansion. In any case, one may want to verify that using more direct measures of slack yields similar results. 
Table 3 reports estimates of the output response to government spending shocks when we use alternative indicators of slack: i) the output gap computed as the deviation of log output from a trend; ii) the detrended unemployment rate; iii) the detrended log employment level; iv) the detrended change in the unemployment rate; v) the detrended change in employment. In all cases, we detrend series using the Hodrick-Prescott filter with smoothing parameter $\lambda=$ $10,000 .^{6}$ While the first three measures are explicitly stock variables, the last two measures are aimed to capture acceleration in an economy. Irrespective of which measure we use, the response in a recession is larger than the response in an expansion. Furthermore, we observe that the response in recession tends to be stronger when we focus on the acceleration measures of the business cycle. In other words, the response of output seems to be larger when an economy starts to contract than when it reaches a bottom. We conclude that cyclical variation in the output responses is robust across a variety of variables measuring the state of business cycle.

Since we have significant variation in macroeconomic characteristics across countries and time, we can explore how some key characteristics are correlated with the size of government spending multipliers. We will examine four characteristics: the level of government debt (as a percent of GDP), openness to trade (mean tariff), an index of the strength of collective relations laws, and an index of labor market regulations. Our approach will be based on the following modification of equation (5):

\footnotetext{
${ }^{6}$ We prefer this value of the smoothing parameter to $\lambda=400$, which is a more conventional value in the literature for semi-annual data, because a larger value ensures that the trend in the Hodrick-Prescott filter does not follow cyclical fluctuations in the series. For example, with $\lambda=400$, the Great Recession does not look like a deep contraction, as the trend significantly falls along with the actual output. In contrast, $\lambda=10,000$ does not produce this counterintuitive result. In any case, our qualitative and, to a large extent, quantitative results are insensitive to the choice of $\lambda$.
} 


$$
\begin{aligned}
Y_{i, t+h}= & \alpha_{i h}+F\left(z_{i t}\right) \boldsymbol{\Pi}_{R, h}(L) Y_{i, t-1}+\left(1-F\left(z_{i t}\right)\right) \boldsymbol{\Pi}_{E, h}(L) Y_{i, t-1} \\
& +F\left(z_{i t}\right) \boldsymbol{\Psi}_{R, h}(L) G_{i, t-1}+\left(1-F\left(z_{i t}\right)\right) \boldsymbol{\Psi}_{E, h}(L) G_{i, t-1} \\
& +F\left(z_{i t}\right) \boldsymbol{\Phi}_{R, h} F E_{i t}^{G}+\left(1-F\left(z_{i t}\right)\right) \boldsymbol{\Phi}_{E, h} F E_{i t}^{G} \\
& +F\left(z_{i t}\right) \widetilde{\boldsymbol{\Phi}}_{R, h} F E_{i t}^{G} Q_{i t}+\left(1-F\left(z_{i t}\right)\right) \widetilde{\boldsymbol{\Phi}}_{E, h} F E_{i t}^{G} Q_{i t}+\mu Q_{i t}+u_{i t}
\end{aligned}
$$

where $Q_{i t}$ is a macroeconomic dimension we would like to study. Coefficients $\boldsymbol{\Phi}_{R, h}$ and $\boldsymbol{\Phi}_{E, h}$ describe the response of $Y$ to a government spending shock $F E_{i t}^{G}$ when $Q_{i t}=0$ (e.g., the debtGDP ratio is zero), while $\left(\boldsymbol{\Phi}_{R, h}+\widetilde{\boldsymbol{\Phi}}_{R, h}\right)$ and $\left(\boldsymbol{\Phi}_{E, h}+\widetilde{\boldsymbol{\Phi}}_{E, h}\right)$ describe the response of $Y$ to a government spending shock $F E_{i t}^{G}$ when $Q_{i t}=1$ (e.g., the debt-GDP ratio is 1). Likewise, we estimate the linear analogue of specification (6) as follows:

$Y_{i, t+h}=\alpha_{i h}+\Pi_{L i n, h}(L) Y_{i, t-1}+\boldsymbol{\Psi}_{L i n, h}(L) G_{i, t-1}+\boldsymbol{\Phi}_{L i n, h} F E_{i t}^{G}+\widetilde{\boldsymbol{\Phi}}_{L i n, h} F E_{i t}^{G} Q_{i t}+u_{i t}$

Table 4 reports mean responses for $\boldsymbol{\Phi}_{R, h}, \boldsymbol{\Phi}_{E, h}, \boldsymbol{\Phi}_{L i n, h}$ and $\left(\boldsymbol{\Phi}_{R, h}+\widetilde{\boldsymbol{\Phi}}_{R, h}\right),\left(\boldsymbol{\Phi}_{E, h}+\widetilde{\boldsymbol{\Phi}}_{E, h}\right)$, $\left(\boldsymbol{\Phi}_{L i n, h}+\widetilde{\boldsymbol{\Phi}}_{\text {Lin,h }}\right)$ over the three year horizon. ${ }^{7}$

Consistent with Perotti (1999) and others, we find that large government debt reduces the response of output to government spending shocks. Specifically, when the level of debt is equal to zero and an economy is in a deep recession, a one percent increase in government spending raises output by approximately 0.73 percent over the course of three years. In contrast, if the level of debt is 100 percent of GDP, then the response of output in a deep recession is just 0.09 percent. Furthermore, the cyclical variation in the size of the output multiplier vanishes as the level of debt approaches 100 percent.

Ilzetzki et al. (2010) report that the government spending multiplier is larger in closed economies than in open economies, which is consistent with textbook macroeconomics. Thus, one may have predicted that closed economies are more likely to have larger multipliers than open economies, but we do not find evidence for this prediction. We find that the size of tariffs

\footnotetext{
${ }^{7}$ We find similar results when all characteristics are included simultaneously.
} 
does not appear to be correlated with the size of the government spending multipliers. ${ }^{8}$ Two observations may help to reconcile this somewhat surprising result. First, the strength of the government spending multiplier depends on the exchange rate regime (floating vs. fixed, capital controls, etc.) in a country. Thus, one may need a more sophisticated set of controls to differentiate how various aspects of international flows of goods and capital influence the size of the multiplier. Second, small open economies with low tariffs (e.g., Belgium) are also more likely to run large fiscal deficits and to accumulate large government debt. To the extent high levels of government debt decrease the size of the fiscal multipliers, one may find that open economies have lower multipliers. Indeed, we find (not shown) that controlling for government debt tends to move the variation in the right direction although it does not resolve the puzzle completely. Thus, a positive correlation between openness and the size of the fiscal multiplier in a recession may be driven by an omitted variable.

One may also expect that a high rigidity of labor markets is likely to lead to more rigid wages and hence amplified responses of output to demand shocks (e.g., Cole and Ohanian (2004), Gorodnichenko, Mendoza and Tesar (2009)). We use two measures of labor market rigidities constructed in Botero et al.’s (2004). The first is an index of protection of labor relations. This index aggregates various dimensions of union strength such as legislative rights to establish unions, to organize strikes, and to collectively bargain. The second index, which we call "labor market regulation," measures how easy it is to fire/hire workers, to increase/decrease hours of work, and to engage in alternative labor contracts (mainly use temporary and part-time workers). We find that as the rigidity in the labor market rises (i.e., either index increases), the output response in recession increases and the cyclical variation in the fiscal multiplier becomes more pronounced. This pattern is consistent with the view that more rigid labor markets can

\footnotetext{
${ }^{8}$ We find similar results for alternative measures of openness, e.g. (export + import)/GDP.
} 
result in enhanced effectiveness of government spending shocks to stimulate output during a downturn.

Overall, we find that variation in the size of the fiscal multiplier is consistent with basic predictions of macroeconomic theory although one should be careful in interpreting the results. Some correlations between macroeconomic dimensions and the size of the fiscal multiplier may be driven by omitted variables. One may also need a more nuanced view on what determines the size of fiscal multipliers.

\section{E. Discussion}

In general, the responses we estimate for key macroeconomic variables are remarkably consistent with the Keynesian view that the size of spending multipliers should vary over the business cycle with fiscal policy being more effective (i.e., larger multipliers) in recessions than in expansions. Interestingly, Gali et al. (2007) argue that new Keynesian models are typically unable to generate an increase in private consumption after a government spending shock. Furthermore, spending multipliers rarely exceed one even in new Keynesian models. In many respects, new Keynesian models are similar to neoclassical models that emphasize crowding out of private consumption by increased government spending. Recently, Woodford (2011) and Christiano et al. (2011) showed theoretically in new Keynesian models that government spending shocks can have large multipliers when zero lower bound (ZLB) on nominal interest rates is binding. Using high-frequency data on interest, inflation and exchange rates, Wieland (2011) provides some empirical support for the spending multipliers to exceed one when there is a binding ZLB. However, the upper bound on multipliers found by Wieland is typically about 1.5, which is considerably smaller than suggested by the theoretical results of Woodford (2011) and Christiano et al. (2011). Furthermore, binding ZLB episodes during recessions have been 
very rare in modern history and thus it is hard to extend this argument more generally to recessions.

The discrepancy between the old and new Keynesian views on the effects of government spending shocks is striking. We conjecture that in part this discrepancy stems from the fact that the notion of slack is largely absent from the new Keynesian models. Indeed, despite having some frictions, new Keynesian models effectively impose clearing factor and product markets and thus there is no spare capacity (or slack) in these model economies. In contrast, old Keynesian models emphasized that markets may not clear at all times and especially in recessions so that crowding out of private consumption or investment by government spending increases in recession can be minimal.

\section{Concluding remarks}

During the Great Recession, countries around the world adopted expansionary fiscal policies aimed at counteracting the large negative shocks to their economies. These actions occurred in spite of skepticism among many economists about the potential of fiscal policy to stimulate economic activity. In the United States, at least, the stage for this active course for fiscal policy was already set by earlier policy developments, which showed a marked increase in fiscal policy activism earlier in the decade (Auerbach and Gale, 2009).

The results in this paper and those in our earlier one suggest that fiscal policy activism may indeed be effective at stimulating output during a deep recession, and that the potential negative side effects of fiscal stimulus, such as increased inflation, are also less likely under these circumstances. These empirical results call into question the results from the new Keynesian literature, which suggests that shocks to government spending, even when increasing output, will crowd out private economic activity. While there has been some recent progress providing a rationale for large multipliers when economies confront a binding zero lower bound 
on interest rates, our findings apply to more general recessionary conditions, and thus present a challenge for the development of new models that, like the simple traditional Keynesian model, can encompass positive fiscal multipliers for private activity.

\section{References}

Auerbach, Alan J., and William G. Gale, 2009. “Activist Fiscal Policy to Stabilize Economic Activity.” Paper presented at the Federal Reserve Bank of Kansas City conference on Financial Stability and Macroeconomic Policy, held August 20-22, 2009.

Auerbach, Alan, and Yuriy Gorodnichenko, 2011. "Measuring the Output Responses to Fiscal Policy,” forthcoming in American Economic Journal: Economic Policy.

Bachmann, Ruediger, and Eric Sims, 2011. "Confidence and the Transmission of Government Spending Shocks,” manuscript.

Blanchard, Olivier, and Roberto Perotti, 2002. “An Empirical Characterization of the Dynamic Effects of Changes in Government Spending and Taxes on Output,” Quarterly Journal of Economics 117(4), 1329-1368.

Botero, Juan, Simeon Djankov, Rafael La Porta, Florencio Lopez-de-Silanes, Andrei Shleifer, 2004. “The regulation of labor,” Quarterly Journal of Economics 119 (4), 1339-1382.

Chodorow-Reich, Gabriel, Laura Feiveson, Zachary Liscow, and William Woolston, 2011. "Does State Fiscal Relief During Recessions Increase Employment? Evidence from the American Recovery and Reinvestment Act,” manuscript.

Christiano, Lawrence, Martin Eichenbaum, and Sergio Rebelo. 2011. "When is the government spending multiplier large?” Journal of Political Economy 119(1), 78-121.

Cole, Harold, and Lee Ohanian, 2004. "New deal policies and the persistence of the great depression: A general equilibrium analysis,” Journal of Political Economy 112(4), 779816.

Driscoll, J.C., A.C. Kraay, 1998. "Consistent Covariance Matrix Estimation With Spatially Dependent Panel Data,” Review of Economics and Statistics 80(4), 549-560.

Gali, Jordi, David Lopez-Salido, and Javier Valles, 2007. "Understanding the Effects of Government Spending on Consumption,” Journal of the European Economic Association, 5, 227-270.

Gorodnichenko, Yuriy, Enrique Mendoza and Linda Tesar, 2009. "The Finnish Great Depression: From Russia with love,” forthcoming in American Economic Review.

Ilzetzki, Ethan, Enrique G. Mendoza, and Carlos A. Végh, 2010. "How Big (Small?) are Fiscal Multipliers?" NBER Working Papers 16479. 
Jorda, Oscar, 2005. “Estimation and Inference of Impulse Responses by Local Projections,” American Economic Review 95(1), 161-182.

Lenain, Patrick, 2002. “What is the track record of OECD Economic Projections?” OECD.

Ramey, Valerie A. 2011. "Identifying Government Spending Shocks: It’s All in the Timing," Quarterly Journal of Economics 126(1): 1-50.

Shoag, Daniel (2010), “The Impact of Government Spending Shocks: Evidence on the Multiplier from State Pension Plan Returns,” manuscript.

Stock, James, and Mark Watson, 2007. "Why Has U.S. Inflation Become Harder to Forecast?” Journal of Money, Banking and Credit 39(1), 3-33.

Vogel, Lukas, 2007. "How Do the OECD Growth Projections for the G7 Economies Perform? A Post-Mortem,” OECD Working Paper No. 573.

Wieland, Johannes, 2011. "Fiscal Multipliers in the Liquidity Trap: International Theory and Evidence,” manuscript.

Wilson , Daniel J., 2010. “Fiscal spending multipliers: evidence from the 2009 American Recovery and Reinvestment Act,” Working Paper Series 2010-17, Federal Reserve Bank of San Francisco.

Woodford, Michael. 2011. "Simple Analytics of the Government Expenditure Multiplier.” American Economic Journal: Macroeconomics 3(1): 1-35. 
Figure 1. Comparison of impulse responses from VAR and direct projection

Panel A: Full sample, 1960-2010.

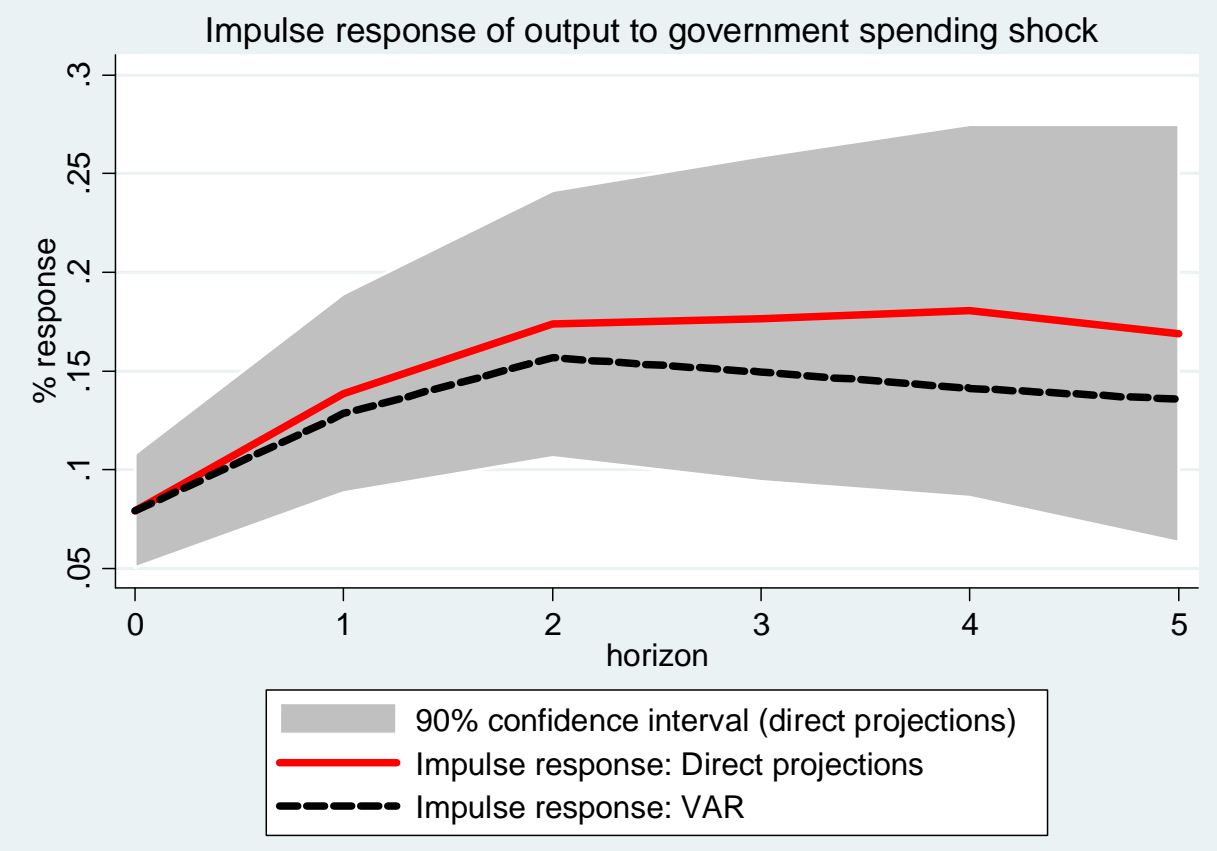

Panel B: Sample for which OECD forecasts are available, 1985-2010.

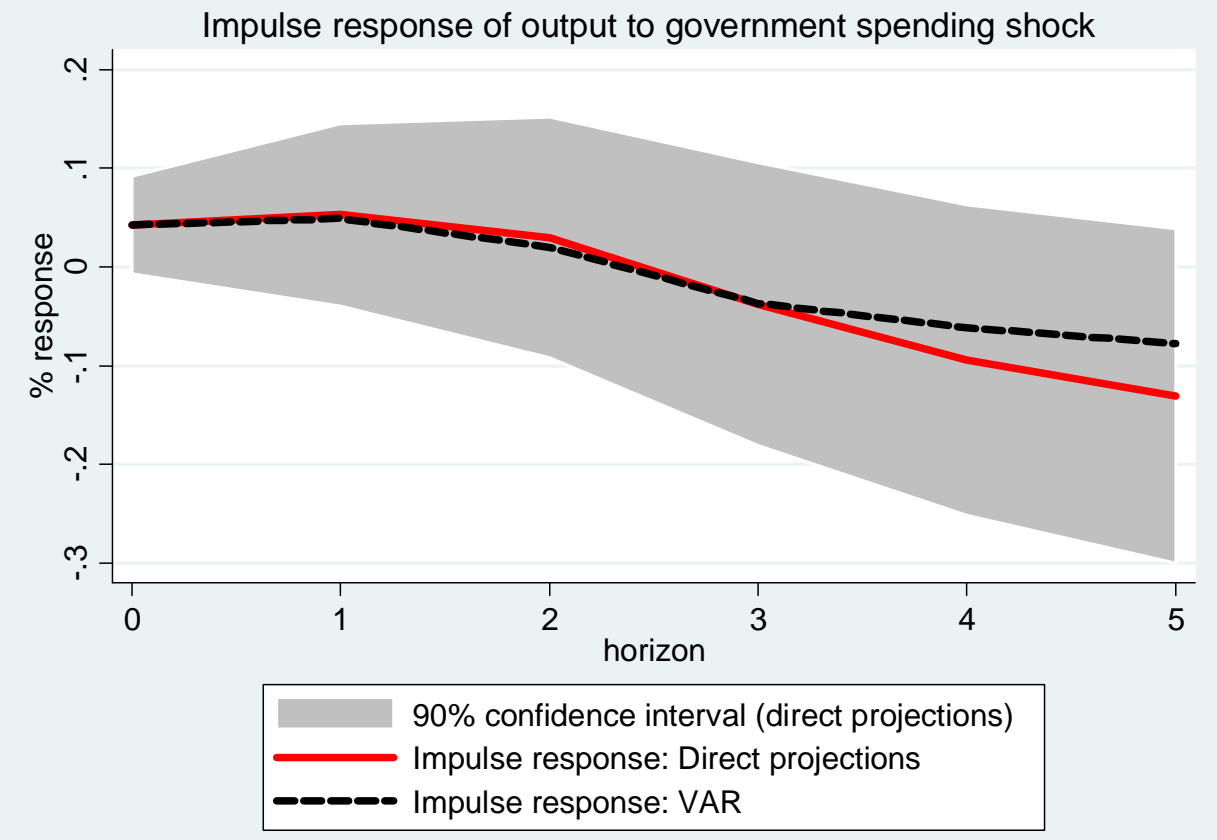


Figure 2. Predictability of VAR shocks to government spending

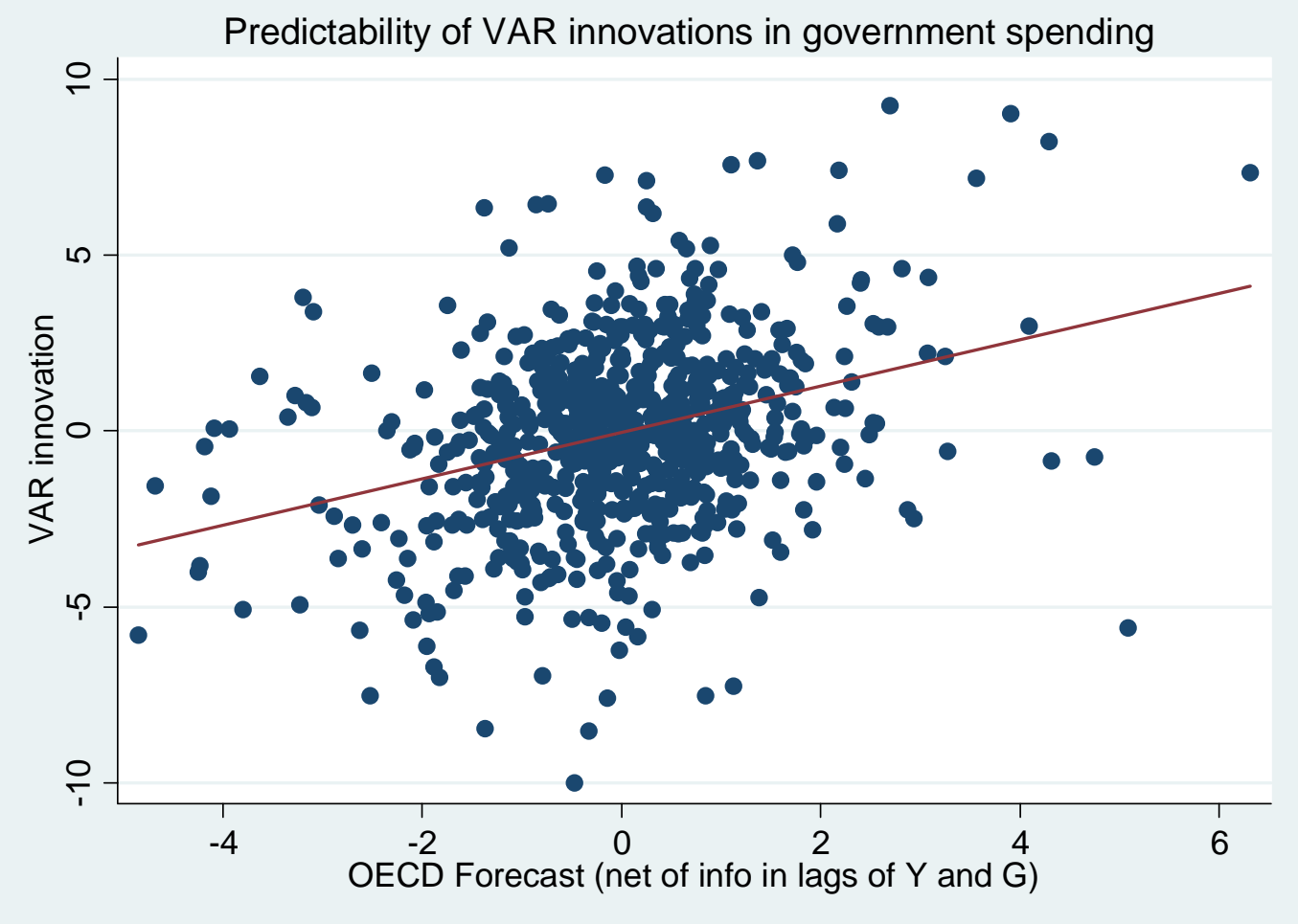

Note: Correlation is 0.36 
Figure 3. Time series of government spending shocks for selected countries.
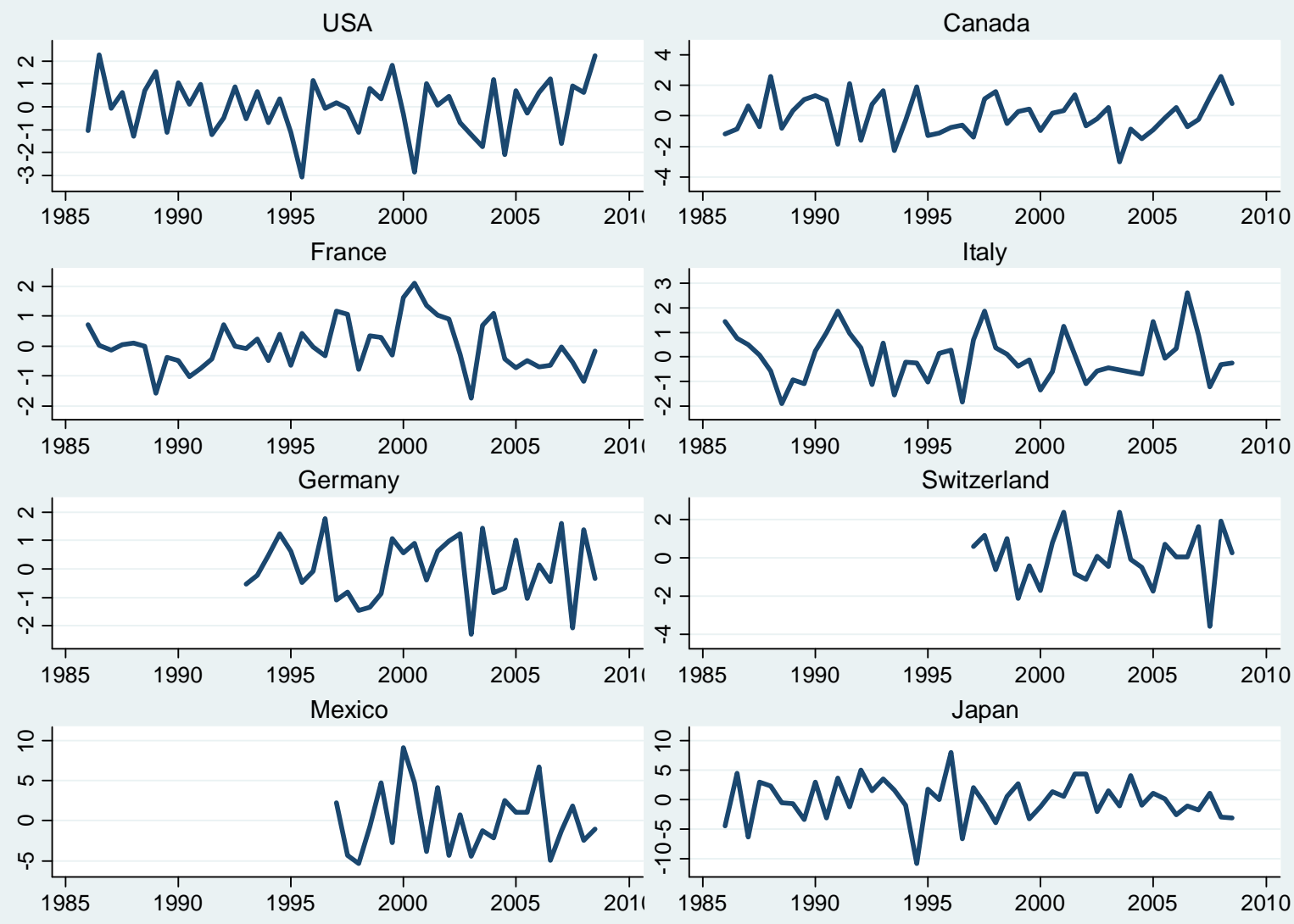
Figure 4. State-dependent vs. Linear responses

Panel A. Real GDP

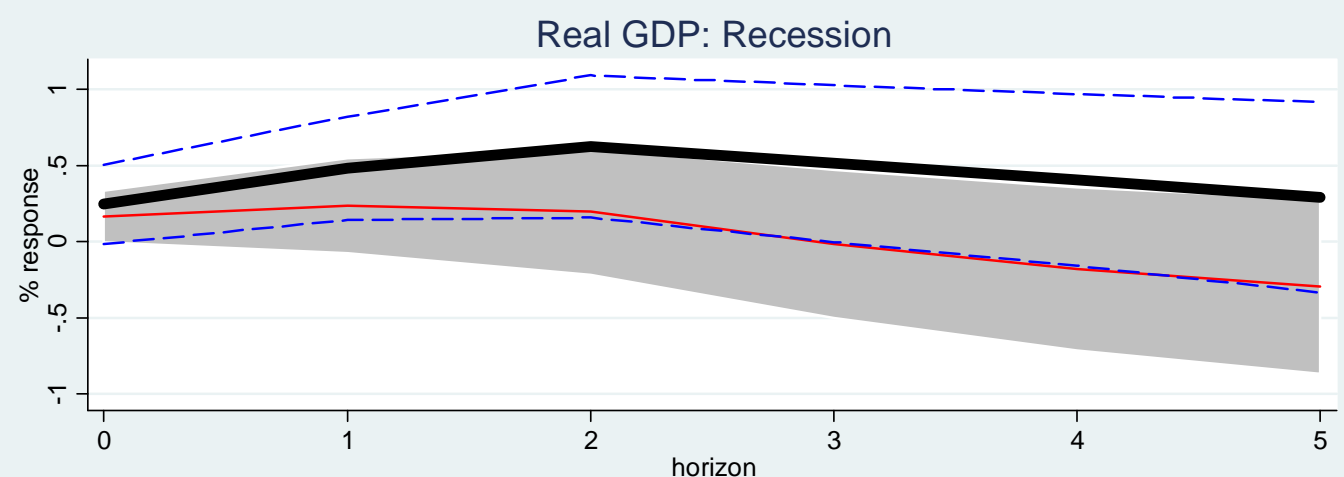

Real GDP: Expansion

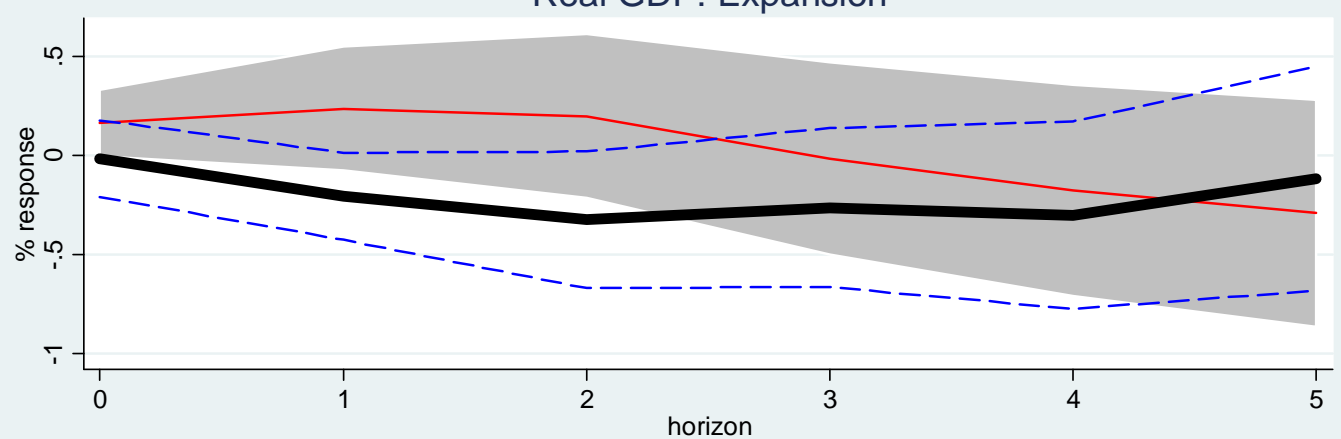

Panel B. Private consumption

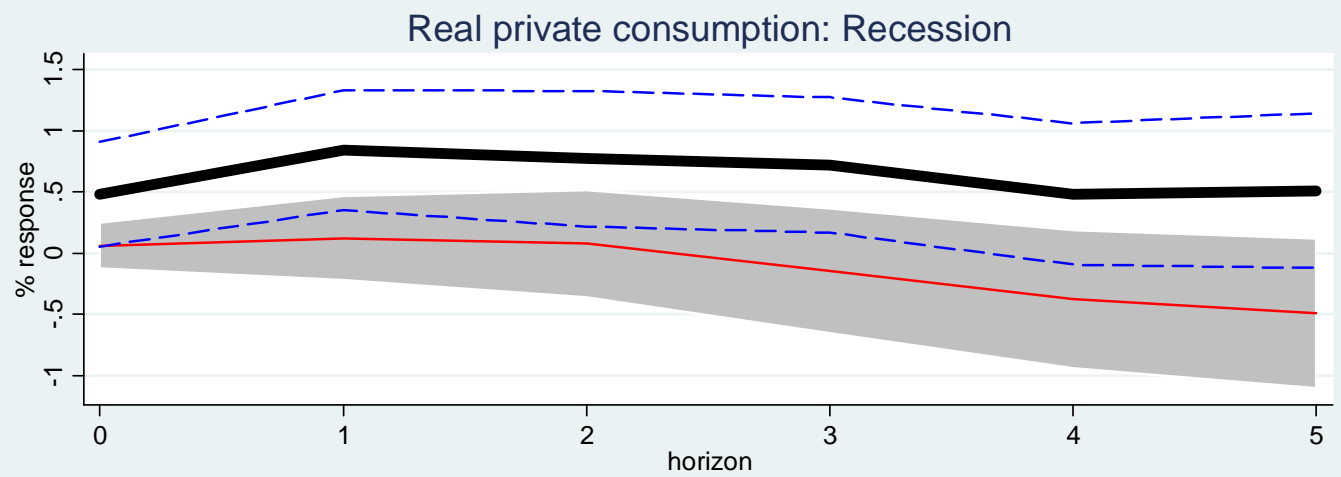

Real private consumption: Expansion

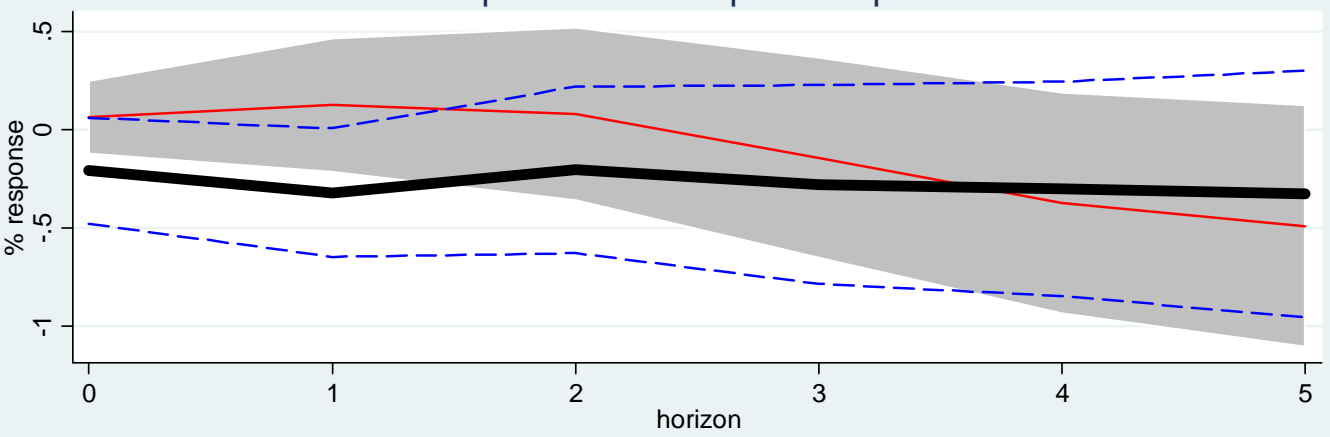

State-dependent response

- - $90 \% \mathrm{Cl}$ for state-dependent response

Linear response

$90 \% \mathrm{Cl}$ for linear response 
Panel C. Private investment

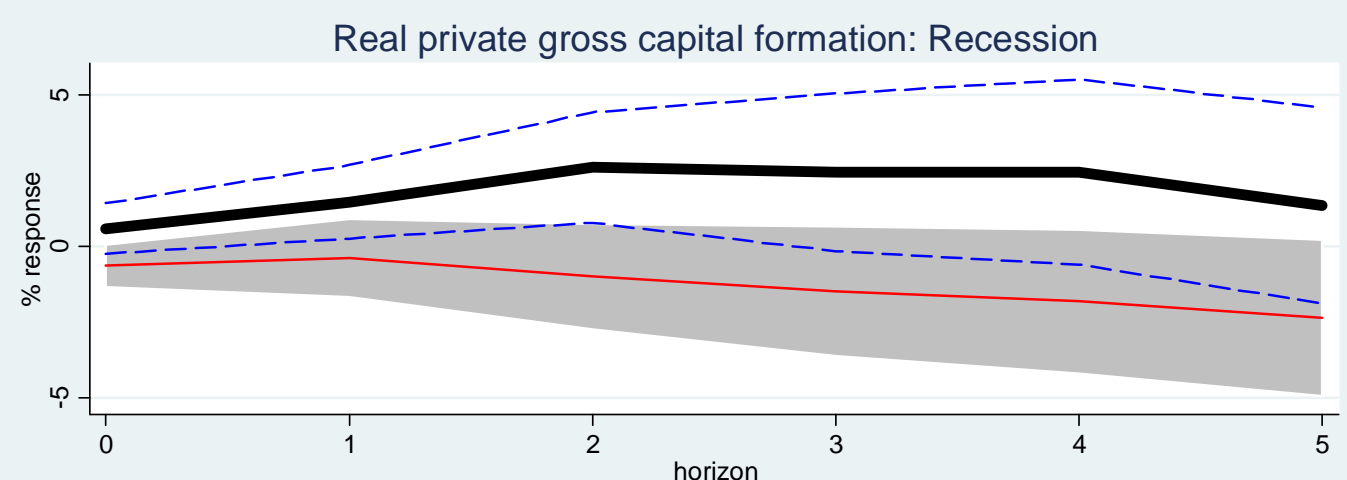

Real private gross capital formation: Expansion

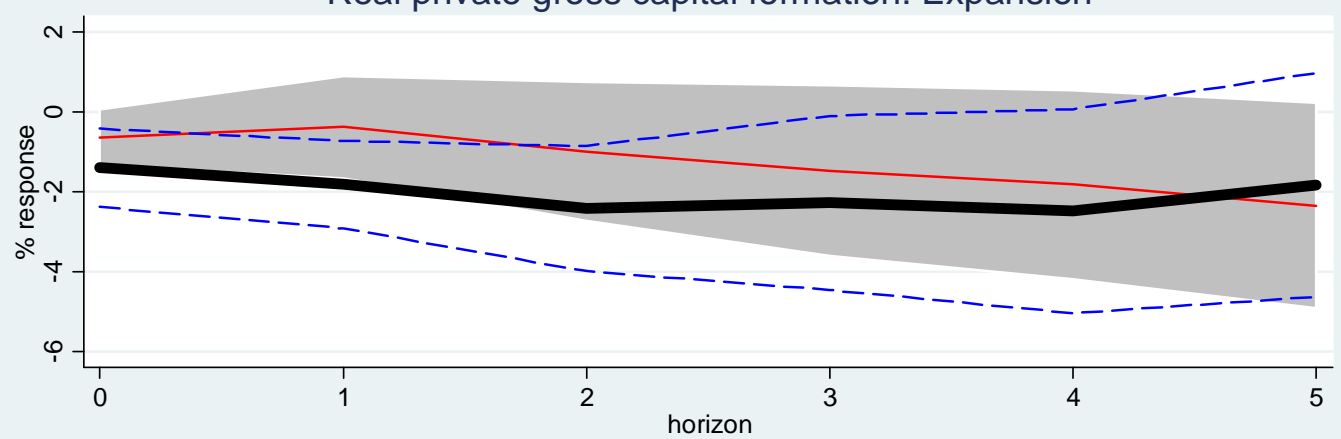

Panel D. Total employment

Total employment: Recession

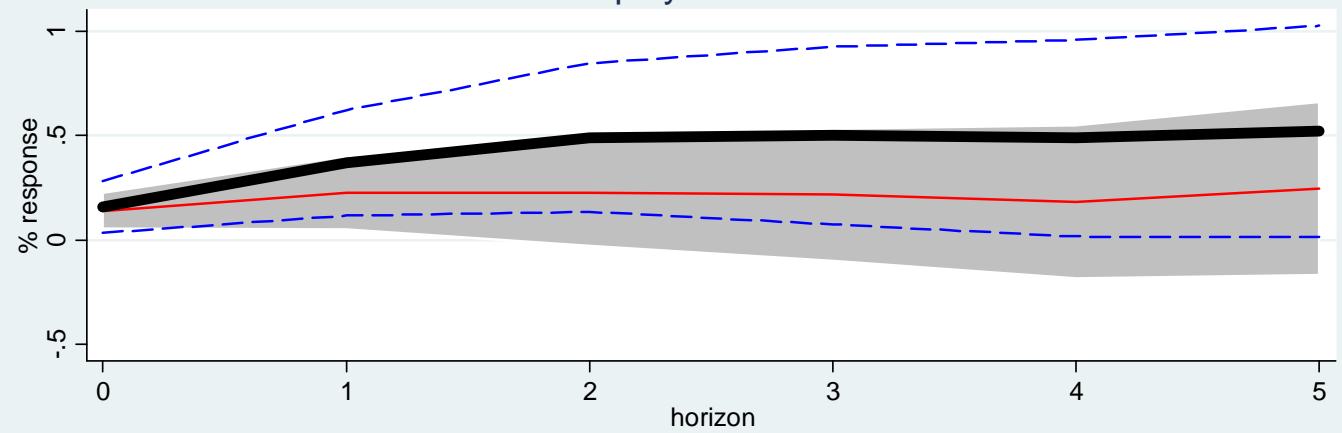

Total employment: Expansion

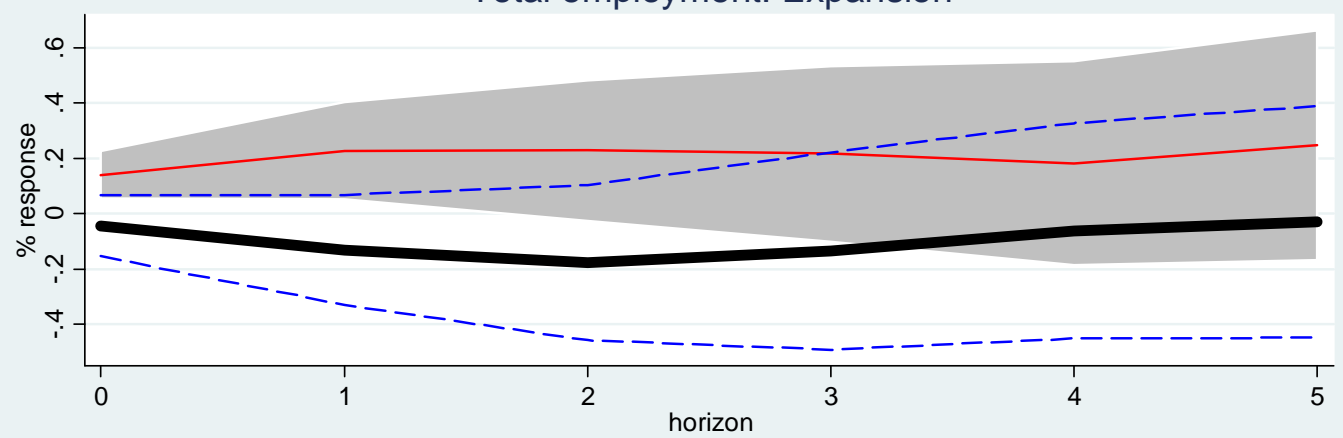

State-dependent response

- - - $90 \% \mathrm{Cl}$ for state-dependent response

Linear response

$90 \% \mathrm{Cl}$ for linear response 
Panel E. Private sector employment

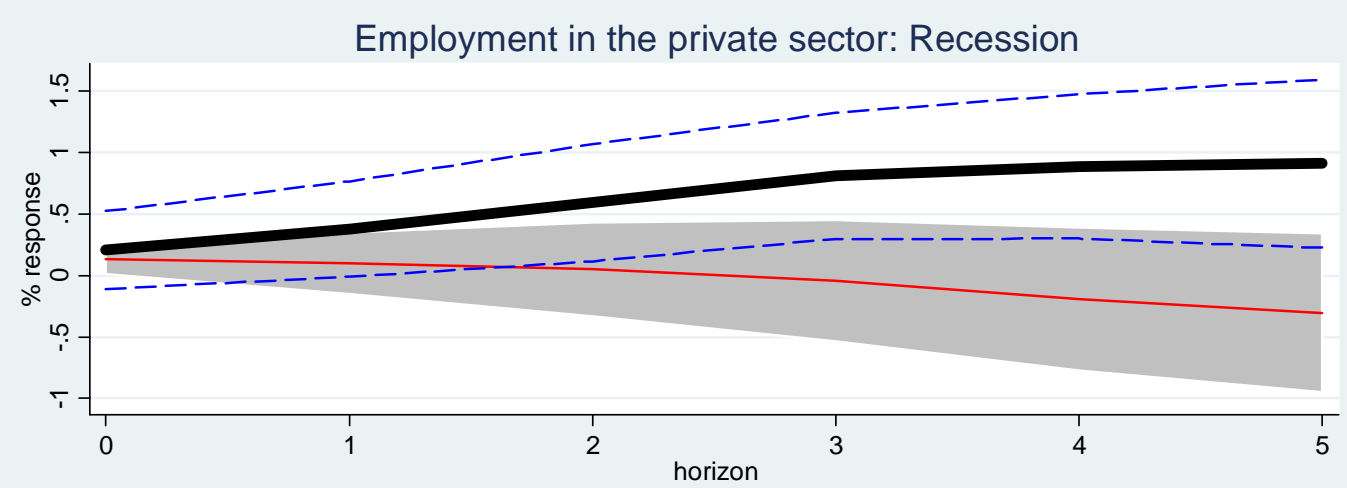

Employment in the private sector: Expansion

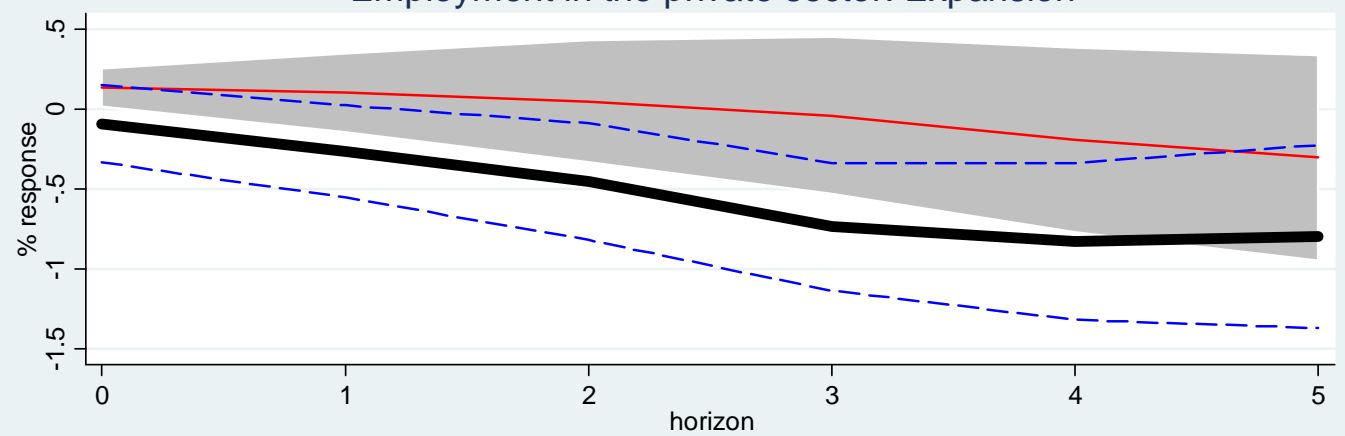

Panel F. Unemployment rate

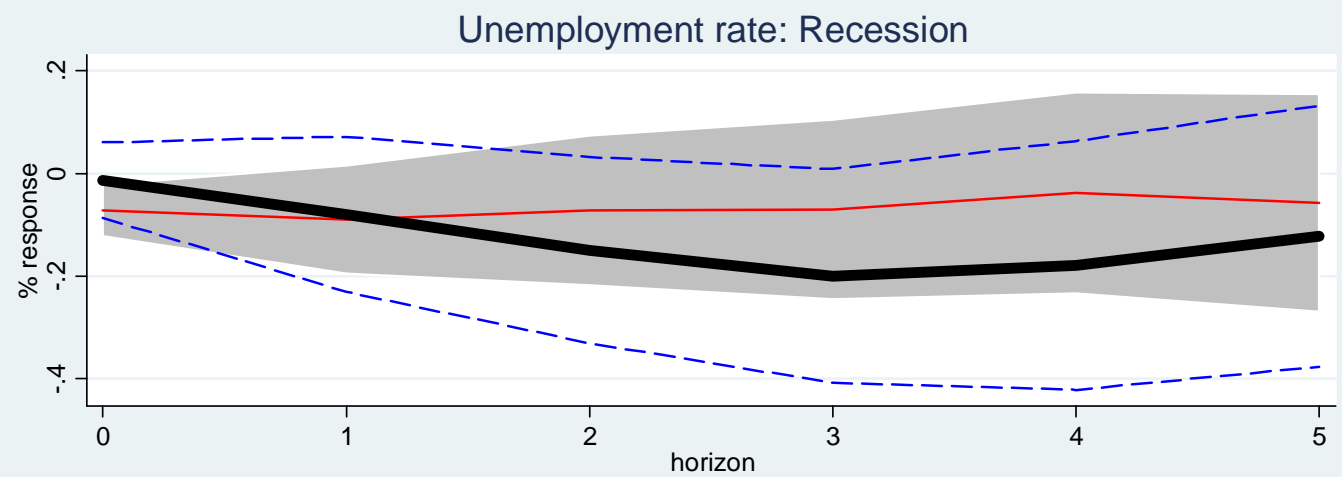

Unemployment rate: Expansion

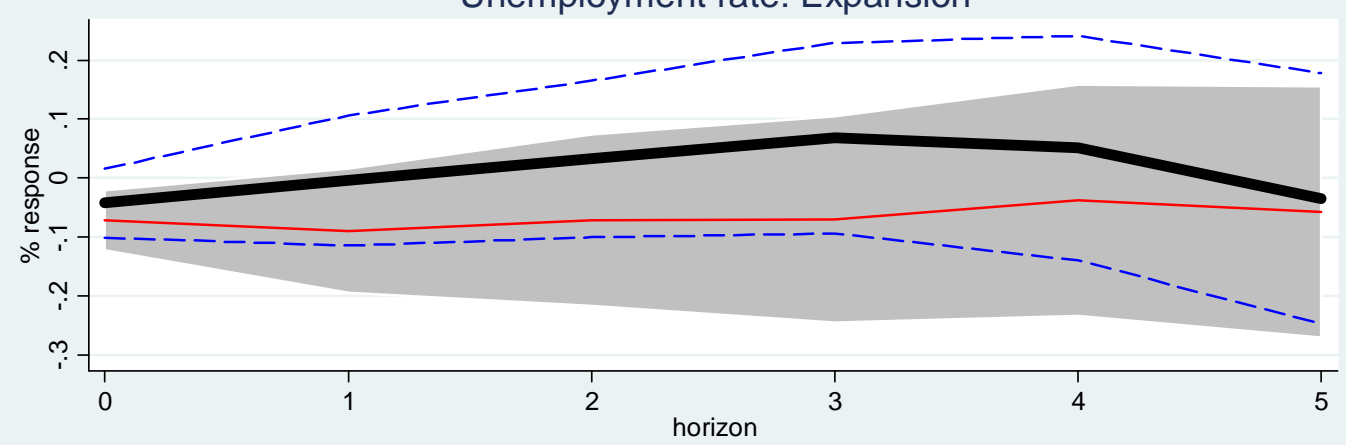

State-dependent response Linear response
--- $90 \% \mathrm{Cl}$ for state-dependent response $90 \% \mathrm{CI}$ for linear response 
Panel G. Real compensation rate of the private sector

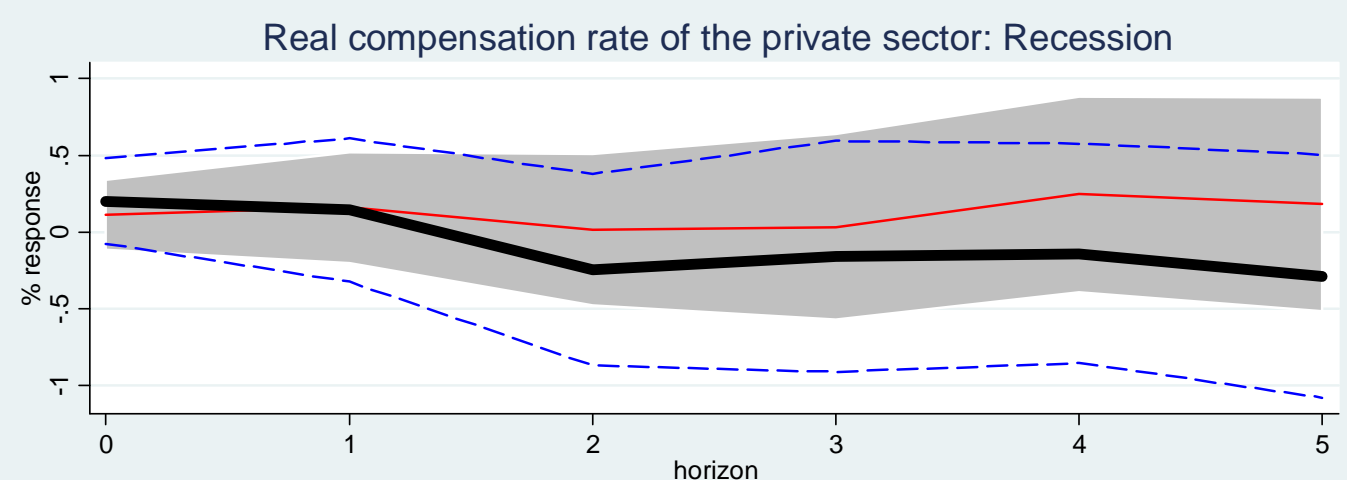

Real compensation rate of the private sector: Expansion

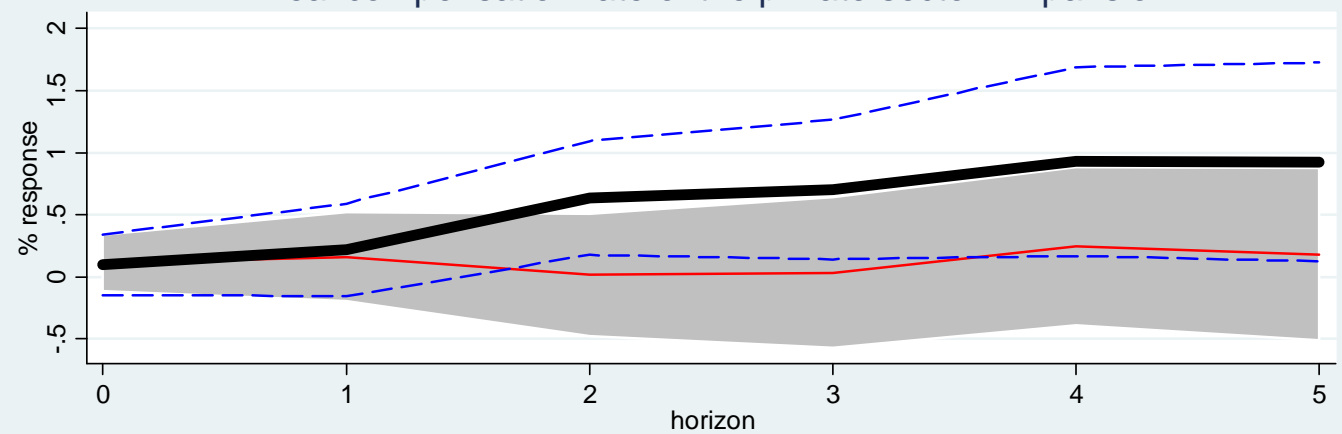

Panel H. Real exports

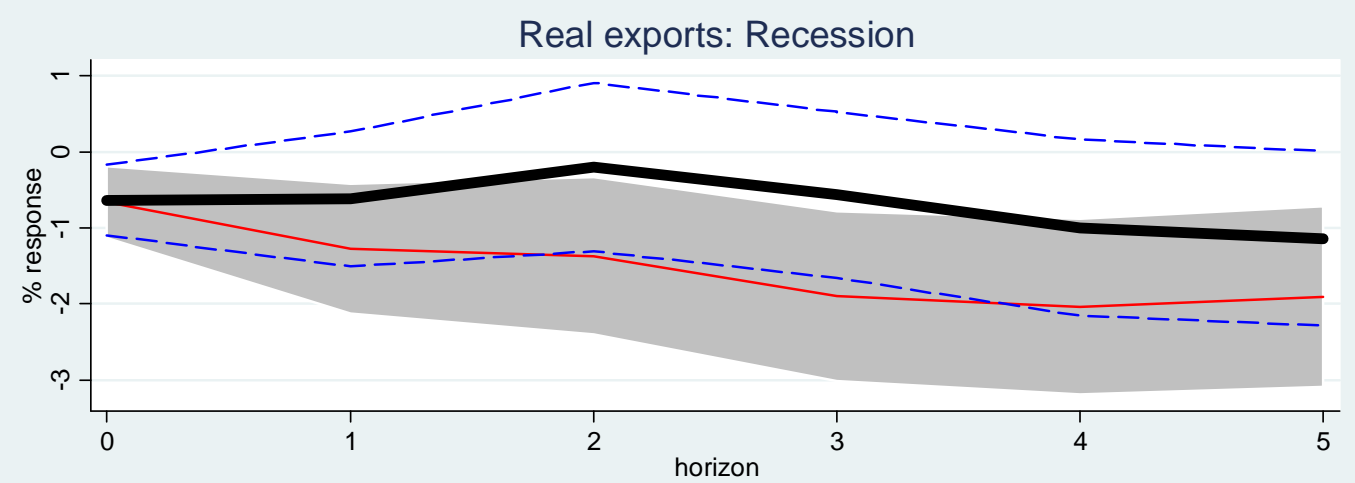

Real exports: Expansion

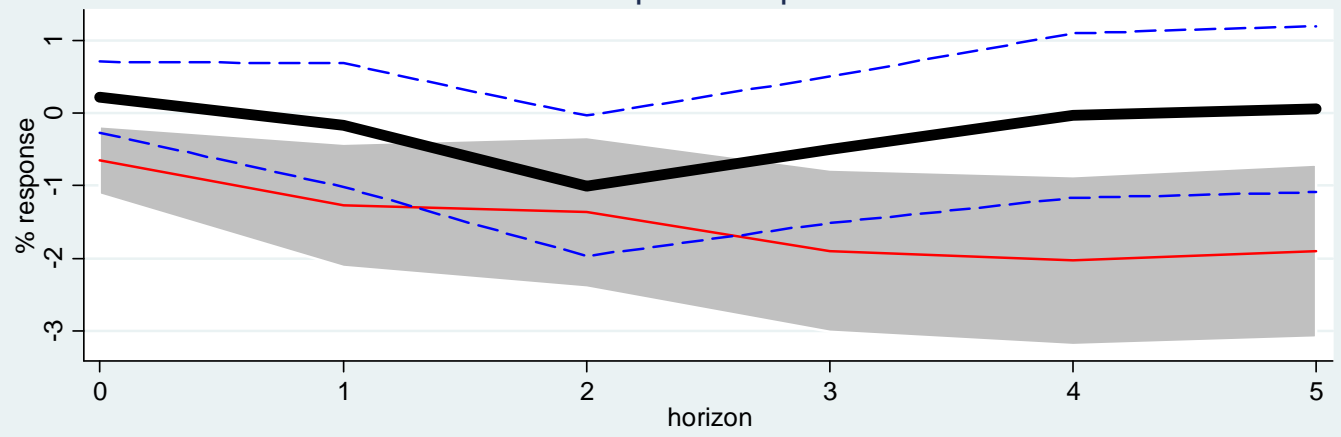

State-dependent response

- - - 90\% Cl for state-dependent response Linear response $90 \% \mathrm{Cl}$ for linear response 
Panel I. Real imports

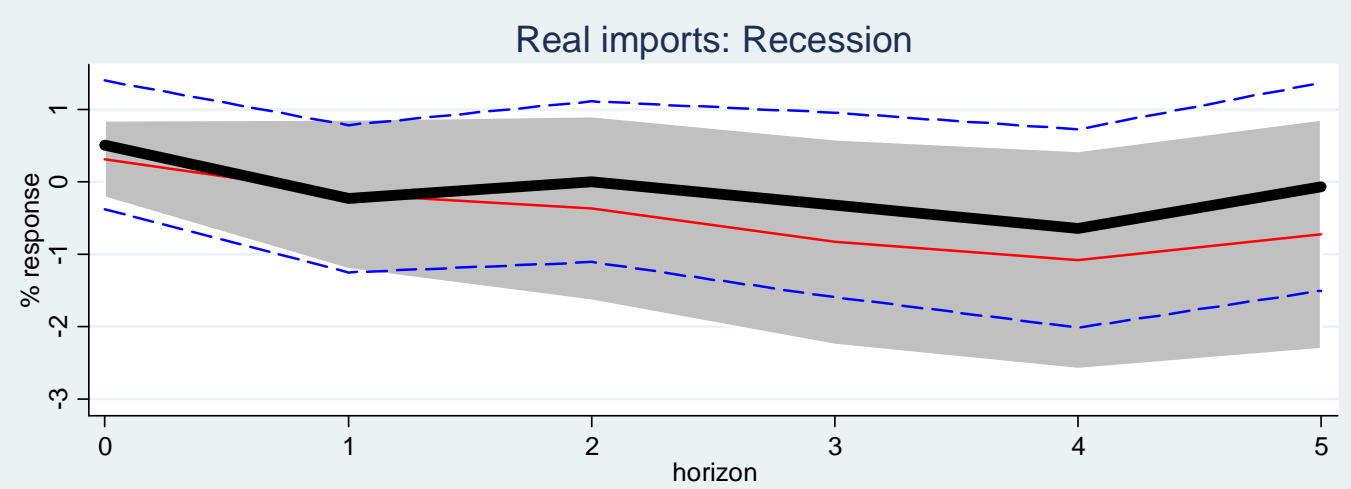

Real imports: Expansion

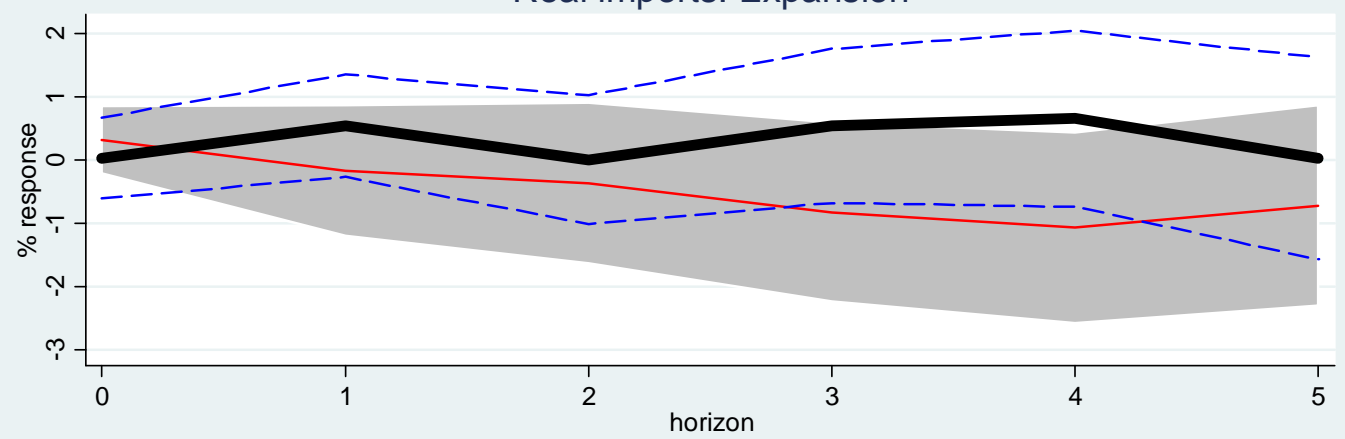

Panel J. Consumer price index

Consumer price index: Recession

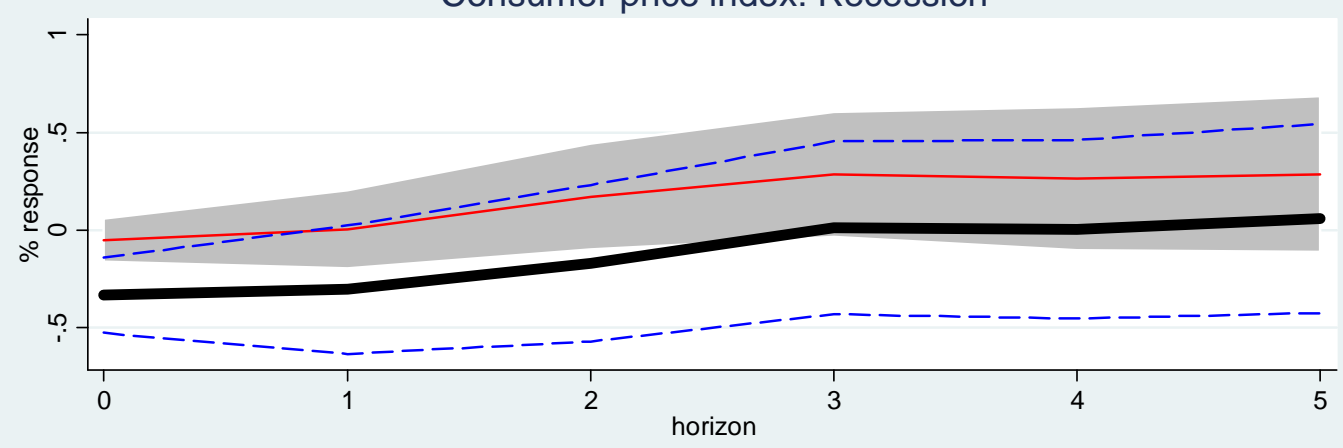

Consumer price index: Expansion

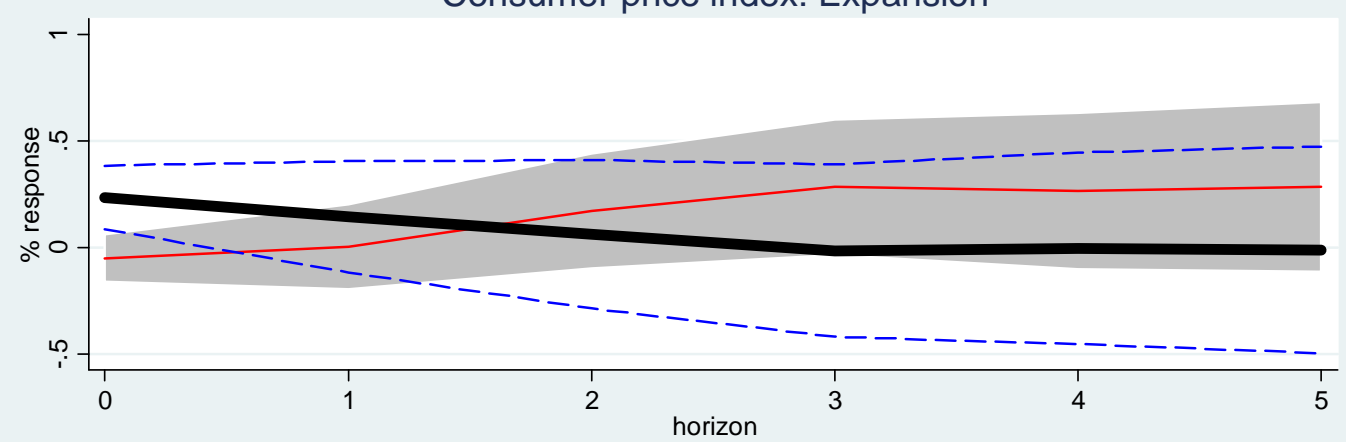

State-dependent response Linear response
-- - $90 \% \mathrm{Cl}$ for state-dependent response $90 \% \mathrm{Cl}$ for linear response 
Panel K. GDP deflator

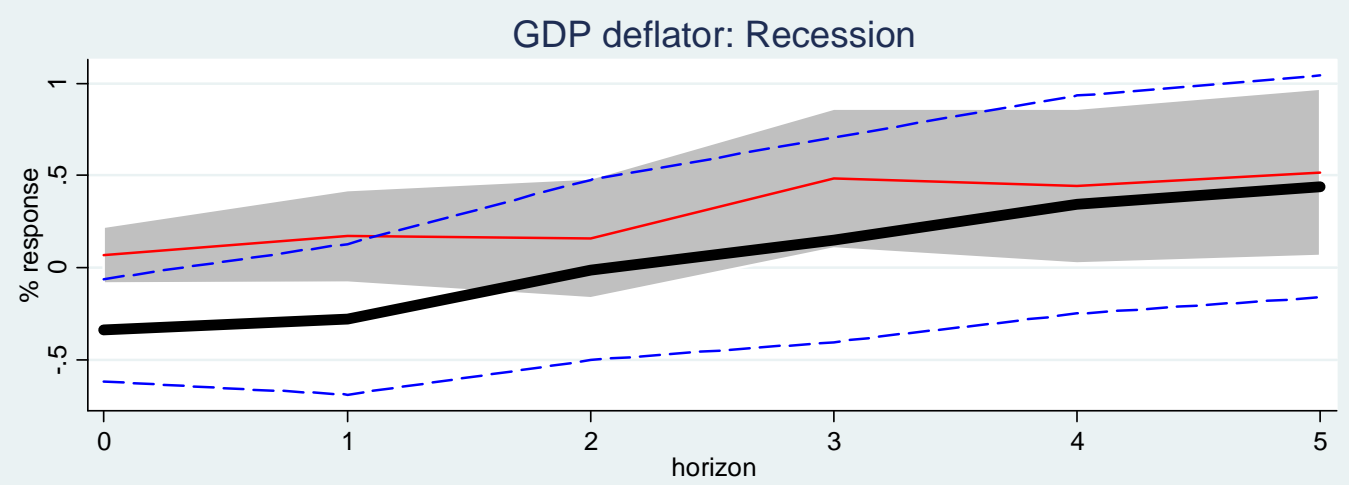

GDP deflator: Expansion

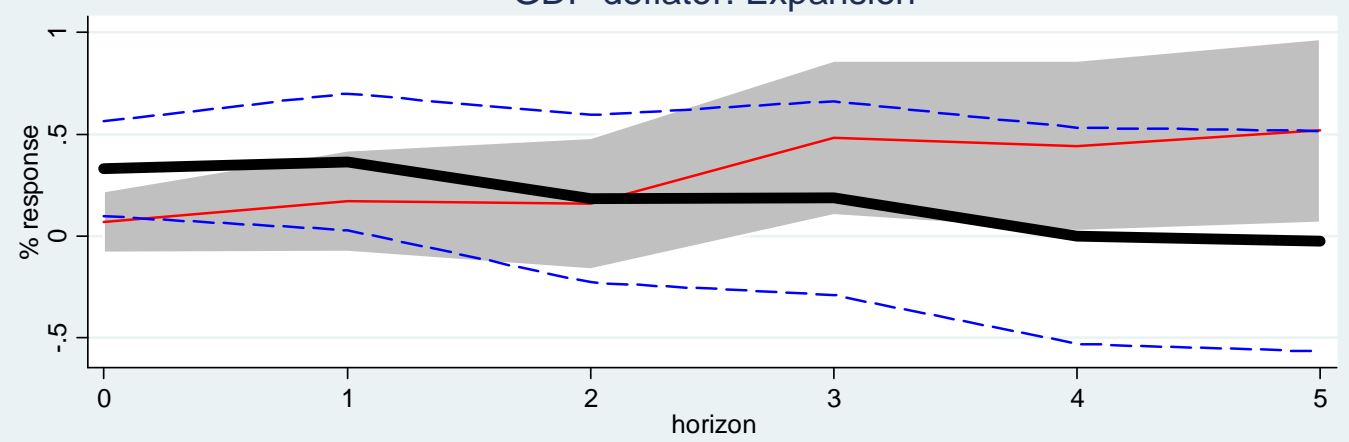

State-dependent response

- - - $90 \% \mathrm{Cl}$ for state-dependent response

Linear response

$90 \% \mathrm{Cl}$ for linear response

Notes: Each panel reports impulse responses for the linear model (5') and the state-dependent model (5) to an unanticipated one-percent government spending shock. 
Table 1. Mean and maximum response to an unanticipated one percent government spending shock.

\begin{tabular}{|c|c|c|c|c|c|c|}
\hline & \multicolumn{3}{|c|}{ Mean response } & \multicolumn{3}{|c|}{ Max response } \\
\hline & $\begin{array}{c}\text { Recession } \\
\frac{1}{1+H} \sum_{h=0}^{H} \boldsymbol{\Phi}_{R, h}\end{array}$ & $\begin{array}{c}\text { Expansion } \\
\frac{1}{1+H} \sum_{h=0}^{H} \boldsymbol{\Phi}_{E, h}\end{array}$ & $\begin{array}{c}\text { Linear } \\
\frac{1}{1+H} \sum_{h=0}^{H} \boldsymbol{\Phi}_{\text {Lin }, h} \\
\end{array}$ & $\begin{array}{l}\text { Recession } \\
\max _{h} \boldsymbol{\Phi}_{R, h}\end{array}$ & $\begin{array}{l}\text { Expansion } \\
\max _{h} \boldsymbol{\Phi}_{E, h} \\
\end{array}$ & $\begin{array}{c}\text { Linear } \\
\max _{h} \boldsymbol{\Phi}_{\text {Lin }, h}\end{array}$ \\
\hline & $(1)$ & $(2)$ & (3) & (4) & (5) & $(6)$ \\
\hline Real GDP & $\begin{array}{c}0.46^{*} \\
(0.26)\end{array}$ & $\begin{array}{l}-0.20 \\
(0.22)\end{array}$ & $\begin{array}{c}0.14 \\
(0.10)\end{array}$ & $\begin{array}{l}0.68 * * \\
(0.34)\end{array}$ & $\begin{array}{c}0.04 \\
(0.09)\end{array}$ & $\begin{array}{c}0.19^{*} \\
(0.11)\end{array}$ \\
\hline Real private consumption & $\begin{array}{l}0.60 * * * \\
(0.24)\end{array}$ & $\begin{array}{l}-0.17 \\
(0.29)\end{array}$ & $\begin{array}{l}0.22^{*} \\
(0.13)\end{array}$ & $\begin{array}{l}0.80^{* * *} \\
(0.24)\end{array}$ & $\begin{array}{l}-0.07 \\
(0.34)\end{array}$ & $\begin{array}{l}0.34 * * * \\
(0.13)\end{array}$ \\
\hline $\begin{array}{l}\text { Real private gross capital } \\
\text { formation }\end{array}$ & $\begin{array}{l}1.92^{*} \\
(1.17)\end{array}$ & $\begin{array}{l}-1.79 \\
(1.10)\end{array}$ & $\begin{array}{c}0.32 \\
(0.43)\end{array}$ & $\begin{array}{c}2.76 \\
(1.96)\end{array}$ & $\begin{array}{l}-0.70 \\
(0.45)\end{array}$ & $\begin{array}{c}0.48 \\
(0.49)\end{array}$ \\
\hline Total employment & $\begin{array}{l}0.45^{* *} \\
(0.20)\end{array}$ & $\begin{array}{l}-0.06 \\
(0.18)\end{array}$ & $\begin{array}{l}0.20 * * \\
(0.09)\end{array}$ & $\begin{array}{l}0.57^{*} \\
(0.33)\end{array}$ & $\begin{array}{l}-0.01 \\
(0.28)\end{array}$ & $\begin{array}{l}0.29 * * * \\
(0.12)\end{array}$ \\
\hline $\begin{array}{l}\text { Employment in the } \\
\text { private sector }\end{array}$ & $\begin{array}{l}0.60 * * * \\
(0.20)\end{array}$ & $\begin{array}{l}-0.53^{* * *} \\
(0.14)\end{array}$ & $\begin{array}{l}-0.07 \\
(0.09)\end{array}$ & $\begin{array}{l}0.88^{* * *} \\
(0.31)\end{array}$ & $\begin{array}{l}-0.09 \\
(0.07)\end{array}$ & $\begin{array}{c}0.02 \\
(0.03)\end{array}$ \\
\hline Unemployment rate & $\begin{array}{l}-0.14^{*} \\
(0.07)\end{array}$ & $\begin{array}{c}0.01 \\
(0.07)\end{array}$ & $\begin{array}{l}-0.07 \\
(0.04)\end{array}$ & $\begin{array}{l}-0.21 * * \\
(0.11)\end{array}$ & $\begin{array}{l}-0.06 * * \\
(0.03)\end{array}$ & $\begin{array}{l}-0.09 * \\
(0.05)\end{array}$ \\
\hline $\begin{array}{l}\text { Real compensation rate of } \\
\text { the private sector }\end{array}$ & $\begin{array}{c}0.02 \\
(0.26)\end{array}$ & $\begin{array}{l}0.64^{*} \\
(0.36)\end{array}$ & $\begin{array}{c}0.31 \\
(0.22)\end{array}$ & $\begin{array}{l}0.23^{*} \\
(0.12)\end{array}$ & $\begin{array}{l}1.14^{* *} \\
(0.55)\end{array}$ & $\begin{array}{c}0.56 \\
(0.34)\end{array}$ \\
\hline Real exports & $\begin{array}{l}-0.57 \\
(0.49)\end{array}$ & $\begin{array}{l}-0.40 \\
(0.44)\end{array}$ & $\begin{array}{l}-0.45^{* * * *} \\
(0.18)\end{array}$ & $\begin{array}{l}-0.01 \\
(0.83)\end{array}$ & $\begin{array}{c}0.01 \\
(0.23)\end{array}$ & $\begin{array}{l}-0.26^{*} \\
(0.14)\end{array}$ \\
\hline Real imports & $\begin{array}{c}0.01 \\
(0.53)\end{array}$ & $\begin{array}{c}0.33 \\
(0.69)\end{array}$ & $\begin{array}{c}0.16 \\
(0.29)\end{array}$ & $\begin{array}{c}0.55 \\
(0.53)\end{array}$ & $\begin{array}{c}0.67 \\
(1.00)\end{array}$ & $\begin{array}{c}0.25 \\
(0.18)\end{array}$ \\
\hline Consumer price index & $\begin{array}{l}-0.12 \\
(0.18)\end{array}$ & $\begin{array}{c}0.07 \\
(0.20)\end{array}$ & $\begin{array}{l}-0.02 \\
(0.09)\end{array}$ & $\begin{array}{c}0.06 \\
(0.25)\end{array}$ & $\begin{array}{l}0.24 * * * \\
(0.08)\end{array}$ & $\begin{array}{c}0.04 \\
(0.13)\end{array}$ \\
\hline GDP deflator & $\begin{array}{c}0.05 \\
(0.19)\end{array}$ & $\begin{array}{c}0.16 \\
(0.24)\end{array}$ & $\begin{array}{c}0.11 \\
(0.12)\end{array}$ & $\begin{array}{c}0.47 \\
(0.32)\end{array}$ & $\begin{array}{c}0.38 \\
(0.23)\end{array}$ & $\begin{array}{c}0.21 \\
(0.17)\end{array}$ \\
\hline Government receipts & $\begin{array}{c}0.26 \\
(0.78)\end{array}$ & $\begin{array}{l}-0.45 \\
(0.64)\end{array}$ & $\begin{array}{l}-0.54^{*} \\
(0.29)\end{array}$ & $\begin{array}{c}0.61 \\
(0.80)\end{array}$ & $\begin{array}{c}0.08 \\
(1.21)\end{array}$ & $\begin{array}{l}-0.19 \\
(0.16)\end{array}$ \\
\hline \multicolumn{7}{|l|}{ Memorandum } \\
\hline $\begin{array}{l}\text { Real GDP (no control } \\
\text { for professional } \\
\text { forecasts) }\end{array}$ & $\begin{array}{c}0.31 \\
(0.33)\end{array}$ & $\begin{array}{l}-0.20 \\
(0.27)\end{array}$ & $\begin{array}{l}-0.02 \\
(0.11)\end{array}$ & $\begin{array}{c}0.43 \\
(0.38)\end{array}$ & $\begin{array}{c}0.06 \\
(0.08)\end{array}$ & $\begin{array}{l}0.12^{* * * *} \\
(0.05)\end{array}$ \\
\hline
\end{tabular}

Notes: The table report percent response of variables indicated in the left column. The estimated specification is given by equations (5) and (5'). For unemployment, columns (4)-(6) show the minimal response. Mean and maximum responses are calculated over three years. Government receipts are nominal. Robust standard errors are reported in parentheses. *, **, *** indicate statistical significance at 10, 5, and 1 percent levels. 
Table 2. Mean and maximum response to an unanticipated one percent government spending shock, control for year fixed effects.

\begin{tabular}{|c|c|c|c|c|c|c|}
\hline & \multicolumn{3}{|c|}{ Mean response } & \multicolumn{3}{|c|}{ Max response } \\
\hline & $\begin{array}{l}\text { Recession } \\
\frac{1}{1+H} \sum_{h=0}^{H} \boldsymbol{\Phi}_{R, h}\end{array}$ & $\begin{array}{l}\text { Expansion } \\
\frac{1}{1+H} \sum_{h=0}^{H} \boldsymbol{\Phi}_{E, h}\end{array}$ & $\begin{array}{c}\text { Linear } \\
\frac{1}{1+H} \sum_{h=0}^{H} \boldsymbol{\Phi}_{\text {Lin, } h} \\
\end{array}$ & $\begin{array}{l}\text { Recession } \\
\max _{h} \boldsymbol{\Phi}_{R, h}\end{array}$ & $\begin{array}{l}\text { Expansion } \\
\max _{h} \boldsymbol{\Phi}_{E, h}\end{array}$ & $\begin{array}{c}\text { Linear } \\
\max _{h} \boldsymbol{\Phi}_{\text {Lin, }}\end{array}$ \\
\hline & $(1)$ & $(2)$ & (3) & $(4)$ & (5) & $(6)$ \\
\hline Real GDP & $\begin{array}{r}0.43^{*} \\
(0.26)\end{array}$ & $\begin{array}{l}-0.19 \\
(0.19)\end{array}$ & $\begin{array}{c}0.18^{*} \\
(0.10)\end{array}$ & $\begin{array}{l}0.67 * * \\
(0.32)\end{array}$ & $\begin{array}{c}0.05 \\
(0.09)\end{array}$ & $\begin{array}{l}0.26^{* *} \\
(0.11)\end{array}$ \\
\hline Real private consumption & $\begin{array}{l}0.60 * * * \\
(0.22)\end{array}$ & $\begin{array}{l}-0.24 \\
(0.26)\end{array}$ & $\begin{array}{l}0.24^{* *} \\
(0.12)\end{array}$ & $\begin{array}{l}0.78^{* * *} \\
(0.23)\end{array}$ & $\begin{array}{l}-0.13 \\
(0.15)\end{array}$ & $\begin{array}{l}0.37 * * * \\
(0.11)\end{array}$ \\
\hline $\begin{array}{l}\text { Real private gross capital } \\
\text { formation }\end{array}$ & $\begin{array}{l}1.63^{*} \\
(0.90)\end{array}$ & $\begin{array}{l}-2.05 * * \\
(0.93)\end{array}$ & $\begin{array}{c}0.09 \\
(0.48)\end{array}$ & $\begin{array}{c}2.27 \\
(1.54)\end{array}$ & $\begin{array}{l}-0.89 * * \\
(0.42)\end{array}$ & $\begin{array}{c}0.26 \\
(0.54)\end{array}$ \\
\hline Total employment & $\begin{array}{l}0.39 * * \\
(0.19)\end{array}$ & $\begin{array}{l}-0.16 \\
(0.18)\end{array}$ & $\begin{array}{l}0.15 \\
(0.10)\end{array}$ & $\begin{array}{c}0.46 \\
(0.32)\end{array}$ & $\begin{array}{l}-0.03 \\
(0.05)\end{array}$ & $\begin{array}{l}0.18^{*} \\
(0.09)\end{array}$ \\
\hline $\begin{array}{l}\text { Employment in the } \\
\text { private sector }\end{array}$ & $\begin{array}{l}0.33^{* *} \\
(0.15)\end{array}$ & $\begin{array}{l}-0.53 * * * \\
(0.14)\end{array}$ & $\begin{array}{l}-0.05 \\
(0.10)\end{array}$ & $\begin{array}{l}0.48^{* *} \\
(0.24)\end{array}$ & $\begin{array}{l}-0.07 \\
(0.06)\end{array}$ & $\begin{array}{c}0.06 \\
(0.06)\end{array}$ \\
\hline Unemployment rate & $\begin{array}{l}-0.12 * \\
(0.07)\end{array}$ & $\begin{array}{c}0.06 \\
(0.07)\end{array}$ & $\begin{array}{l}-0.04 \\
(0.04)\end{array}$ & $\begin{array}{l}-0.19 * * \\
(0.10)\end{array}$ & $\begin{array}{l}-0.02 \\
(0.05)\end{array}$ & $\begin{array}{l}-0.07 * * \\
(0.03)\end{array}$ \\
\hline $\begin{array}{l}\text { Real compensation rate of } \\
\text { the private sector }\end{array}$ & $\begin{array}{l}-0.13 \\
(0.32)\end{array}$ & $\begin{array}{c}0.56^{*} \\
(0.32)\end{array}$ & $\begin{array}{c}0.23 \\
(0.21)\end{array}$ & $\begin{array}{c}0.13 \\
(0.13)\end{array}$ & $\begin{array}{c}0.92^{*} \\
(0.54)\end{array}$ & $\begin{array}{c}0.36 \\
(0.35)\end{array}$ \\
\hline Real exports & $\begin{array}{l}-0.04 \\
(0.34)\end{array}$ & $\begin{array}{l}-0.39 \\
(0.28)\end{array}$ & $\begin{array}{l}-0.15 \\
(0.16)\end{array}$ & $\begin{array}{c}0.67 \\
(0.61)\end{array}$ & $\begin{array}{c}0.04 \\
(0.66)\end{array}$ & $\begin{array}{l}-0.04 \\
(0.24)\end{array}$ \\
\hline Real imports & $\begin{array}{c}0.62 \\
(0.47)\end{array}$ & $\begin{array}{c}0.01 \\
(0.53)\end{array}$ & $\begin{array}{l}0.40 * * \\
(0.21)\end{array}$ & $\begin{array}{c}0.88^{*} \\
(0.50)\end{array}$ & $\begin{array}{c}0.41 \\
(0.56)\end{array}$ & $\begin{array}{l}0.56^{* *} \\
(0.26)\end{array}$ \\
\hline Consumer price index & $\begin{array}{l}-0.06 \\
(0.16)\end{array}$ & $\begin{array}{l}-0.01 \\
(0.17)\end{array}$ & $\begin{array}{l}-0.02 \\
(0.08)\end{array}$ & $\begin{array}{c}0.07 \\
(0.20)\end{array}$ & $\begin{array}{l}0.18 * * * \\
(0.06)\end{array}$ & $\begin{array}{c}0.02 \\
(0.12)\end{array}$ \\
\hline GDP deflator & $\begin{array}{l}-0.00 \\
(0.18)\end{array}$ & $\begin{array}{c}0.12 \\
(0.23)\end{array}$ & $\begin{array}{c}0.08 \\
(0.12)\end{array}$ & $\begin{array}{c}0.33 \\
(0.33)\end{array}$ & $\begin{array}{c}0.35 \\
(0.23)\end{array}$ & $\begin{array}{c}0.13 \\
(0.15)\end{array}$ \\
\hline Government receipts & $\begin{array}{l}-0.08 \\
(0.48)\end{array}$ & $\begin{array}{l}-0.51 \\
(0.36)\end{array}$ & $\begin{array}{l}-0.56 * * * \\
(0.24)\end{array}$ & $\begin{array}{c}0.30 \\
(0.51)\end{array}$ & $\begin{array}{l}-0.09 \\
(0.68)\end{array}$ & $\begin{array}{l}-0.14 \\
(0.17)\end{array}$ \\
\hline Memorandum & & & & & & \\
\hline $\begin{array}{l}\text { Real GDP (no control } \\
\text { for professional } \\
\text { forecasts) } \\
\end{array}$ & $\begin{array}{c}0.27 \\
(0.32)\end{array}$ & $\begin{array}{l}-0.05 \\
(0.24)\end{array}$ & $\begin{array}{c}0.10 \\
(0.08)\end{array}$ & $\begin{array}{c}0.48 \\
(0.38)\end{array}$ & $\begin{array}{c}0.10 \\
(0.44)\end{array}$ & $\begin{array}{l}0.16^{* * * *} \\
(0.05)\end{array}$ \\
\hline
\end{tabular}

Notes: The table report percent response of variables indicated in the left column. The estimated specification is given by equations (5) and (5'). For unemployment, columns (4)-(6) show the minimal response. Mean and maximum responses are calculated over three years. Robust standard errors are reported in parentheses. ${ }^{*}, * *, * * *$ indicate statistical significance at 10,5 , and 1 percent levels. 
Table 3. Alternative measures of business cycle conditions.

\begin{tabular}{|c|c|c|c|c|}
\hline \multirow{3}{*}{$\begin{array}{l}\text { Variable measuring } \\
\text { the state of the business cycle }\end{array}$} & \multicolumn{2}{|c|}{ Mean response } & \multicolumn{2}{|c|}{ Max response } \\
\hline & $\begin{array}{l}\text { Recession } \\
\frac{1}{1+H} \sum_{h=0}^{H} \boldsymbol{\Phi}_{R, h}\end{array}$ & $\begin{array}{l}\text { Expansion } \\
\frac{1}{1+H} \sum_{h=0}^{H} \boldsymbol{\Phi}_{E, h}\end{array}$ & $\begin{array}{l}\text { Recession } \\
\max _{h} \boldsymbol{\Phi}_{R, h}\end{array}$ & $\begin{array}{l}\text { Expansion } \\
\max _{h} \boldsymbol{\Phi}_{E, h}\end{array}$ \\
\hline & $(1)$ & $(2)$ & $(3)$ & $(4)$ \\
\hline \multicolumn{5}{|c|}{ Panel A: country fixed effects } \\
\hline 6 quarter moving average of GDP & $0.46^{*}$ & -0.20 & $0.68 * *$ & 0.04 \\
\hline growth rate (baseline) & $(0.26)$ & $(0.22)$ & $(0.34)$ & $(0.09)$ \\
\hline \multirow[t]{2}{*}{ Output gap } & 0.45 & -0.05 & 0.61 & 0.13 \\
\hline & $(0.32)$ & $(0.23)$ & $(0.40)$ & $(0.37)$ \\
\hline \multirow[t]{2}{*}{ Unemployment rate } & 0.41 & -0.10 & $0.52 * *$ & 0.06 \\
\hline & $(0.25)$ & $(0.23)$ & $(0.26)$ & $(0.35)$ \\
\hline \multirow[t]{2}{*}{ Change in unemployment rate } & $1.03^{* *}$ & $-0.88 * *$ & $1.27 * *$ & $-0.48 *$ \\
\hline & $(0.47)$ & $(0.45)$ & $(0.58)$ & $(0.27)$ \\
\hline \multirow[t]{2}{*}{ Employment gap } & 0.36 & -0.09 & $0.50 * * *$ & 0.01 \\
\hline & $(0.24)$ & $(0.16)$ & $(0.20)$ & $(0.33)$ \\
\hline \multirow[t]{2}{*}{ Growth rate of employment } & $0.92 *$ & -0.74 & $1.15^{* *}$ & -0.34 \\
\hline & $(0.51)$ & $(0.48)$ & $(0.59)$ & $(0.28)$ \\
\hline & \multicolumn{4}{|c|}{ Panel B: country and time fixed effects } \\
\hline 6 quarter moving average of GDP & $0.43^{*}$ & -0.19 & $0.67 * *$ & 0.05 \\
\hline growth rate (baseline) & $(0.26)$ & $(0.19)$ & $(0.32)$ & $(0.09)$ \\
\hline \multirow[t]{2}{*}{ Output gap } & $0.48 *$ & -0.04 & $0.64 * *$ & 0.10 \\
\hline & $(0.27)$ & $(0.18)$ & $(0.30)$ & $(0.21)$ \\
\hline \multirow[t]{2}{*}{ Unemployment rate } & $0.50 * *$ & -0.11 & $0.64 * * *$ & 0.05 \\
\hline & $(0.22)$ & $(0.15)$ & $(0.27)$ & $(0.10)$ \\
\hline \multirow[t]{2}{*}{ Change in unemployment rate } & $0.75^{* *}$ & -0.50 & $0.87^{* *}$ & -0.27 \\
\hline & $(0.37)$ & $(0.32)$ & $(0.43)$ & $(0.27)$ \\
\hline \multirow[t]{2}{*}{ Employment gap } & $0.35^{*}$ & -0.00 & $0.46 * * *$ & 0.12 \\
\hline & $(0.20)$ & $(0.16)$ & $(0.18)$ & $(0.18)$ \\
\hline \multirow[t]{2}{*}{ Growth rate of employment } & 0.48 & -0.24 & $0.86 * *$ & 0.11 \\
\hline & $(0.46)$ & $(0.40)$ & $(0.44)$ & $(0.58)$ \\
\hline
\end{tabular}

Notes: The table reports estimates of equation (5) for alternative choices of the variable $z$ which captures the state of the business cycle. Output gap and Employment gap are computed as deviation from Hodrick-Prescott filter with smoothing parameters $\lambda=10,000$. Change in unemployment rate and Growth rate of employment are detrended the Hodrick-Prescott filter with smoothing parameters $\lambda=$ 10,000. All data are semi-annual. Mean and maximum responses are calculated over three years. Robust standard errors are reported in parentheses. *, **, *** indicate statistical significance at 10,5 , and 1 percent levels. 
Table 4. Variation in the mean response of output across countries.

\begin{tabular}{|c|c|c|c|c|c|c|}
\hline \multirow{3}{*}{$\begin{array}{l}\text { Macroeconomic } \\
\text { characteristic }\end{array}$} & \multicolumn{3}{|c|}{$\begin{array}{c}\text { Response when characteristic is equal to } \\
\text { zero percent }\end{array}$} & \multicolumn{3}{|c|}{$\begin{array}{l}\text { Response when characteristic is equal to } \\
100 \text { percent }\end{array}$} \\
\hline & $\begin{array}{l}\text { Recession } \\
\frac{\sum_{h=0}^{H} \boldsymbol{\Phi}_{R, h}}{1+H}\end{array}$ & $\begin{array}{c}\text { Expansion } \\
\frac{\sum_{h=0}^{H} \boldsymbol{\Phi}_{E, h}}{1+H}\end{array}$ & $\begin{array}{c}\text { Linear } \\
\frac{\sum_{h=0}^{H} \boldsymbol{\Phi}_{\text {Lin }, h}}{1+H}\end{array}$ & $\begin{array}{c}\text { Recession } \\
\frac{\sum_{h=0}^{H}\left(\boldsymbol{\Phi}_{R, h}+\widetilde{\boldsymbol{\Phi}}_{R, h}\right)}{1+H}\end{array}$ & $\begin{array}{c}\text { Expansion } \\
\frac{\sum_{h=0}^{H}\left(\boldsymbol{\Phi}_{E, h^{+}}+\widetilde{\Phi}_{E, h}\right)}{1+H}\end{array}$ & $\begin{array}{c}\text { Linear } \\
\frac{\sum_{h=0}^{H}\left(\boldsymbol{\Phi}_{L i n, h}+\widetilde{\boldsymbol{\Phi}}_{L i n, h}\right)}{1+H}\end{array}$ \\
\hline & $(1)$ & $(2)$ & (3) & $(4)$ & $(5)$ & $(6)$ \\
\hline \multicolumn{7}{|c|}{ Panel A: country fixed effects } \\
\hline Level of government debt & $\begin{array}{l}0.84 * * * \\
(0.32)\end{array}$ & $\begin{array}{l}-0.58 \\
(0.38)\end{array}$ & $\begin{array}{c}0.22 \\
(0.17)\end{array}$ & $\begin{array}{c}0.05 \\
(0.35)\end{array}$ & $\begin{array}{c}0.26 \\
(0.36)\end{array}$ & $\begin{array}{c}0.04 \\
(0.16)\end{array}$ \\
\hline Openness to trade & $\begin{array}{l}1.13^{* *} \\
(0.51)\end{array}$ & $\begin{array}{l}-0.34 \\
(0.39)\end{array}$ & $\begin{array}{c}0.04 \\
(0.24)\end{array}$ & $\begin{array}{l}0.97 * * \\
(0.44)\end{array}$ & $\begin{array}{l}-0.32 \\
(0.35)\end{array}$ & $\begin{array}{c}0.04 \\
(0.21)\end{array}$ \\
\hline Protection of collective relations & $\begin{array}{l}-0.61 \\
(0.59)\end{array}$ & $\begin{array}{l}-0.33 \\
(0.63)\end{array}$ & $\begin{array}{l}-0.51 * * \\
(0.23)\end{array}$ & $\begin{array}{l}2.28 * * * \\
(0.79)\end{array}$ & $\begin{array}{l}-0.37 \\
(0.64)\end{array}$ & $\begin{array}{l}0.91 * * \\
(0.41)\end{array}$ \\
\hline Labor market regulation & $\begin{array}{c}0.09 \\
(0.47)\end{array}$ & $\begin{array}{c}0.18 \\
(0.44)\end{array}$ & $\begin{array}{c}0.17 \\
(0.18)\end{array}$ & $\begin{array}{l}1.34^{* *} \\
(0.59)\end{array}$ & $\begin{array}{l}-0.99 * * * \\
(0.36)\end{array}$ & $\begin{array}{l}-0.01 \\
(0.36)\end{array}$ \\
\hline \multicolumn{7}{|c|}{ Panel B: country and time fixed effects } \\
\hline Level of government debt & $\begin{array}{l}0.90 * * * \\
(0.34)\end{array}$ & $\begin{array}{l}-0.61 * \\
(0.34)\end{array}$ & $\begin{array}{c}0.24 \\
(0.16)\end{array}$ & $\begin{array}{l}-0.30 \\
(0.30)\end{array}$ & $\begin{array}{c}0.42 \\
(0.33)\end{array}$ & $\begin{array}{c}0.08 \\
(0.15)\end{array}$ \\
\hline Openness to trade & $\begin{array}{l}1.10 * * \\
(0.54)\end{array}$ & $\begin{array}{l}-0.66 * \\
(0.38)\end{array}$ & $\begin{array}{c}0.12 \\
(0.20)\end{array}$ & $\begin{array}{l}0.96 * * \\
(0.45)\end{array}$ & $\begin{array}{l}-0.58 * \\
(0.34)\end{array}$ & $\begin{array}{c}0.11 \\
(0.17)\end{array}$ \\
\hline Protection of collective relations & $\begin{array}{l}-0.20 \\
(0.49)\end{array}$ & $\begin{array}{l}-0.72 \\
(0.46)\end{array}$ & $\begin{array}{l}-0.43^{* * *} \\
(0.13)\end{array}$ & $\begin{array}{l}1.65^{* * *} \\
(0.74)\end{array}$ & $\begin{array}{c}0.11 \\
(0.57)\end{array}$ & $\begin{array}{l}0.93^{* * *} \\
(0.35)\end{array}$ \\
\hline Labor market regulation & $\begin{array}{l}-0.08 \\
(0.35)\end{array}$ & $\begin{array}{c}0.26 \\
(0.30)\end{array}$ & $\begin{array}{c}0.14 \\
(0.20)\end{array}$ & $\begin{array}{l}1.49 * * * \\
(0.51)\end{array}$ & $\begin{array}{l}-1.05^{* * * *} \\
(0.39)\end{array}$ & $\begin{array}{c}0.16 \\
(0.32)\end{array}$ \\
\hline
\end{tabular}

Notes: The table reports estimates of equations (6) and (6'). Level of government debt is measured as percent of GDP (Source: OECD). Openness to trade is the mean tariff measured in percent of value of traded goods (Source: World Bank). Protection of collective relations is an index ranging from zero (weak protection of collective labor relations) to one (high protection). This index is from Botero et al. (2004). Labor market regulation is an index raging from zero (low regulation) and one (high regulation). This index is from Botero et al. (2004). Robust standard errors are reported in parentheses. $*, * *, * * *$ indicate statistical significance at 10,5 , and 1 percent levels. 


\section{Appendix: Additional Tables}

Table A1. Mean and maximum response (over one year horizon) to an unanticipated one percent government spending shock.

\begin{tabular}{|c|c|c|c|c|c|c|}
\hline & \multicolumn{3}{|c|}{ Mean response } & \multicolumn{3}{|c|}{ Max response } \\
\hline & $\begin{array}{l}\text { Recession } \\
\frac{\sum_{h=0}^{H} \Phi_{R, h}}{1+H} \\
(1)\end{array}$ & $\begin{array}{l}\text { Expansion } \\
\frac{\sum_{h=0}^{H} \Phi_{E, h}}{1+H} \\
(2)\end{array}$ & $\begin{array}{c}\text { Linear } \\
\frac{\sum_{h=0}^{H} \boldsymbol{\Phi}_{\text {Lin }, h}}{1+H} \\
(3)\end{array}$ & $\begin{array}{c}\text { Recession } \\
\max _{h} \boldsymbol{\Phi}_{R, h} \\
(4)\end{array}$ & $\begin{array}{l}\text { Expansion } \\
\max _{h} \boldsymbol{\Phi}_{E, h} \\
\text { (5) }\end{array}$ & $\begin{array}{c}\text { Linear } \\
\max _{h} \boldsymbol{\Phi}_{\text {Lin }, h} \\
\text { (6) }\end{array}$ \\
\hline \multirow[t]{2}{*}{ Real GDP } & $0.35 * *$ & -0.09 & $0.14 * *$ & $0.53 * * *$ & 0.04 & $0.15^{*}$ \\
\hline & $(0.18)$ & $(0.10)$ & $(0.07)$ & $(0.22)$ & $(0.09)$ & $(0.08)$ \\
\hline \multirow[t]{2}{*}{ Real private consumption } & $0.62 * * *$ & -0.18 & $0.21 * * *$ & $0.80 * * *$ & -0.14 & $0.29 * * *$ \\
\hline & $(0.22)$ & $(0.16)$ & $(0.08)$ & $(0.24)$ & $(0.15)$ & $(0.10)$ \\
\hline \multirow{2}{*}{$\begin{array}{l}\text { Real private gross capital } \\
\text { formation }\end{array}$} & $0.96 *$ & $-1.06 * *$ & 0.16 & $1.34^{* *}$ & -0.70 & 0.23 \\
\hline & $(0.52)$ & $(0.47)$ & $(0.30)$ & $(0.58)$ & $(0.45)$ & $(0.37)$ \\
\hline \multirow[t]{2}{*}{ Total employment } & $0.28 * * *$ & -0.06 & $0.11^{* * *}$ & $0.39 * * *$ & -0.02 & $0.15^{* * *}$ \\
\hline & $(0.10)$ & $(0.08)$ & $(0.04)$ & $(0.13)$ & $(0.06)$ & $(0.06)$ \\
\hline \multirow{2}{*}{$\begin{array}{l}\text { Employment in the } \\
\text { private sector }\end{array}$} & $0.26 * *$ & $-0.17 *$ & 0.00 & $0.35 * *$ & -0.09 & 0.02 \\
\hline & $(0.13)$ & $(0.09)$ & $(0.05)$ & $(0.18)$ & $(0.07)$ & $(0.03)$ \\
\hline \multirow[t]{2}{*}{ Unemployment rate } & -0.05 & -0.04 & $-0.05 * *$ & -0.08 & $-0.06 * *$ & $-0.06 *$ \\
\hline & $(0.04)$ & $(0.03)$ & $(0.03)$ & $(0.06)$ & $(0.03)$ & $(0.04)$ \\
\hline \multirow{2}{*}{$\begin{array}{c}\text { Real compensation rate of } \\
\text { the private sector }\end{array}$} & 0.20 & 0.18 & 0.14 & $0.23 *$ & 0.23 & 0.15 \\
\hline & $(0.18)$ & $(0.22)$ & $(0.12)$ & $(0.12)$ & $(0.29)$ & $(0.14)$ \\
\hline \multirow[t]{2}{*}{ Real exports } & $-0.54 *$ & -0.28 & $-0.38 * *$ & -0.47 & 0.01 & $-0.26^{*}$ \\
\hline & $(0.31)$ & $(0.32)$ & $(0.17)$ & $(0.44)$ & $(0.23)$ & $(0.14)$ \\
\hline \multirow[t]{2}{*}{ Real imports } & 0.23 & 0.18 & 0.19 & 0.55 & 0.41 & 0.25 \\
\hline & $(0.56)$ & $(0.46)$ & $(0.24)$ & $(0.53)$ & $(0.60)$ & $(0.18)$ \\
\hline \multirow[t]{2}{*}{ Consumer price index } & $-0.32 * * *$ & 0.19 & -0.05 & $-0.30 *$ & $0.24 * * *$ & -0.03 \\
\hline & $(0.13)$ & $(0.12)$ & $(0.05)$ & $(0.18)$ & $(0.08)$ & $(0.04)$ \\
\hline \multirow[t]{2}{*}{ GDP deflator } & $-0.33^{* *}$ & $0.37 * *$ & 0.04 & -0.30 & 0.38 & 0.06 \\
\hline & $(0.16)$ & $(0.19)$ & $(0.09)$ & $(0.20)$ & $(0.23)$ & $(0.11)$ \\
\hline \multirow[t]{2}{*}{ Government receipts } & 0.31 & -0.41 & $-0.37^{*}$ & 0.47 & -0.15 & -0.19 \\
\hline & $(0.45)$ & $(0.35)$ & $(0.20)$ & $(0.62)$ & $(0.26)$ & $(0.16)$ \\
\hline
\end{tabular}

Notes: The table report percent response of variables indicated in the left column. The estimated specification is given by equation (5). For unemployment, columns (4)-(6) show the minimal response. Mean and maximum responses are calculated over three years. Government receipts are nominal. Robust standard errors are reported in parentheses. *, **, *** indicate statistical significance at 10,5 , and 1 percent levels. 
Table A2. Mean and maximum response (over one year horizon) to an unanticipated one percent government spending shock, control for year fixed effects.

\begin{tabular}{|c|c|c|c|c|c|c|}
\hline & \multicolumn{3}{|c|}{ Mean response } & \multicolumn{3}{|c|}{ Max response } \\
\hline & $\begin{array}{l}\text { Recession } \\
\frac{\sum_{h=0}^{H} \Phi_{R, h}}{1+H} \\
(1)\end{array}$ & $\begin{array}{c}\text { Expansion } \\
\frac{\sum_{h=0}^{H} \Phi_{E, h}}{1+H} \\
(2) \\
\end{array}$ & $\begin{array}{c}\text { Linear } \\
\sum_{h=0}^{H} \boldsymbol{\Phi}_{\text {Lin, }} \\
1+H \\
(3)\end{array}$ & $\begin{array}{c}\text { Recession } \\
\max _{h} \boldsymbol{\Phi}_{R, h} \\
(4) \\
\end{array}$ & $\begin{array}{c}\text { Expansion } \\
\max _{h} \boldsymbol{\Phi}_{E, h} \\
(5) \\
\end{array}$ & $\begin{array}{c}\text { Linear } \\
\max _{h} \boldsymbol{\Phi}_{\text {Lin, }} \\
\text { (6) } \\
\end{array}$ \\
\hline Real GDP & $\begin{array}{c}0.33^{*} \\
(0.18)\end{array}$ & $\begin{array}{l}-0.05 \\
(0.09)\end{array}$ & $\begin{array}{l}0.19 * * * \\
(0.07)\end{array}$ & $\begin{array}{l}0.48 * * \\
(0.22)\end{array}$ & $\begin{array}{c}0.05 \\
(0.09)\end{array}$ & $\begin{array}{l}0.23 * * * \\
(0.09)\end{array}$ \\
\hline Real private consumption & $\begin{array}{l}0.60 * * * \\
(0.22)\end{array}$ & $\begin{array}{l}-0.18 \\
(0.15)\end{array}$ & $\begin{array}{l}0.24^{* * *} \\
(0.08)\end{array}$ & $\begin{array}{l}0.78^{* * *} \\
(0.23)\end{array}$ & $\begin{array}{l}-0.13 \\
(0.15)\end{array}$ & $\begin{array}{l}0.33 * * * \\
(0.09)\end{array}$ \\
\hline $\begin{array}{l}\text { Real private gross capital } \\
\text { formation }\end{array}$ & $\begin{array}{l}0.95^{* *} \\
(0.46)\end{array}$ & $\begin{array}{l}-1.22 * * * \\
(0.43)\end{array}$ & $\begin{array}{c}0.11 \\
(0.29)\end{array}$ & $\begin{array}{l}1.18^{* *} \\
(0.51)\end{array}$ & $\begin{array}{l}-0.89 * * \\
(0.42)\end{array}$ & $\begin{array}{c}0.13 \\
(0.36)\end{array}$ \\
\hline Total employment & $\begin{array}{l}0.26^{* * *} \\
(0.09)\end{array}$ & $\begin{array}{l}-0.07 \\
(0.08)\end{array}$ & $\begin{array}{l}0.11^{* * *} \\
(0.04)\end{array}$ & $\begin{array}{l}0.36 * * * \\
(0.13)\end{array}$ & $\begin{array}{l}-0.03 \\
(0.05)\end{array}$ & $\begin{array}{l}0.15^{* * *} \\
(0.06)\end{array}$ \\
\hline $\begin{array}{l}\text { Employment in the } \\
\text { private sector }\end{array}$ & $\begin{array}{c}0.17 \\
(0.11)\end{array}$ & $\begin{array}{l}-0.13 \\
(0.09)\end{array}$ & $\begin{array}{c}0.06 \\
(0.04)\end{array}$ & $\begin{array}{c}0.20 \\
(0.16)\end{array}$ & $\begin{array}{l}-0.07 \\
(0.06)\end{array}$ & $\begin{array}{c}0.06 \\
(0.06)\end{array}$ \\
\hline Unemployment rate & $\begin{array}{l}-0.04 \\
(0.05)\end{array}$ & $\begin{array}{l}-0.04 \\
(0.03)\end{array}$ & $\begin{array}{l}-0.06^{* *} \\
(0.03)\end{array}$ & $\begin{array}{l}-0.07 \\
(0.06)\end{array}$ & $\begin{array}{l}-0.02 \\
(0.05)\end{array}$ & $\begin{array}{l}-0.07^{* *} \\
(0.03)\end{array}$ \\
\hline $\begin{array}{c}\text { Real compensation rate of } \\
\text { the private sector }\end{array}$ & $\begin{array}{c}0.09 \\
(0.18)\end{array}$ & $\begin{array}{c}0.22 \\
(0.19)\end{array}$ & $\begin{array}{c}0.15 \\
(0.11)\end{array}$ & $\begin{array}{c}0.13 \\
(0.13)\end{array}$ & $\begin{array}{c}0.26 \\
(0.25)\end{array}$ & $\begin{array}{c}0.15 \\
(0.10)\end{array}$ \\
\hline Real exports & $\begin{array}{l}-0.17 \\
(0.25)\end{array}$ & $\begin{array}{l}-0.24 \\
(0.20)\end{array}$ & $\begin{array}{l}-0.12 \\
(0.13)\end{array}$ & $\begin{array}{c}0.06 \\
(0.34)\end{array}$ & $\begin{array}{l}-0.03 \\
(0.19)\end{array}$ & $\begin{array}{l}-0.11 \\
(0.17)\end{array}$ \\
\hline Real imports & $\begin{array}{c}0.55 \\
(0.55)\end{array}$ & $\begin{array}{c}0.16 \\
(0.46)\end{array}$ & $\begin{array}{l}0.43 * * * \\
(0.17)\end{array}$ & $\begin{array}{c}0.73 \\
(0.53)\end{array}$ & $\begin{array}{c}0.41 \\
(0.56)\end{array}$ & $\begin{array}{l}0.48^{* *} \\
(0.21)\end{array}$ \\
\hline Consumer price index & $\begin{array}{l}-0.22 * * \\
(0.10)\end{array}$ & $\begin{array}{c}0.13 \\
(0.09)\end{array}$ & $\begin{array}{l}-0.04 \\
(0.04)\end{array}$ & $\begin{array}{l}-0.19 \\
(0.14)\end{array}$ & $\begin{array}{l}0.18^{* * *} \\
(0.06)\end{array}$ & $\begin{array}{l}-0.03 \\
(0.04)\end{array}$ \\
\hline GDP deflator & $\begin{array}{l}-0.32^{* *} \\
(0.14)\end{array}$ & $\begin{array}{c}0.35^{*} \\
(0.19)\end{array}$ & $\begin{array}{c}0.03 \\
(0.09)\end{array}$ & $\begin{array}{l}-0.29 \\
(0.18)\end{array}$ & $\begin{array}{c}0.35 \\
(0.23)\end{array}$ & $\begin{array}{c}0.05 \\
(0.10)\end{array}$ \\
\hline Government receipts & $\begin{array}{c}0.25 \\
(0.42)\end{array}$ & $\begin{array}{l}-0.43 \\
(0.28)\end{array}$ & $\begin{array}{l}-0.30 \\
(0.20)\end{array}$ & $\begin{array}{c}0.30 \\
(0.51)\end{array}$ & $\begin{array}{l}-0.22 \\
(0.27)\end{array}$ & $\begin{array}{l}-0.14 \\
(0.17)\end{array}$ \\
\hline
\end{tabular}

Notes: The table report percent response of variables indicated in the left column. The estimated specification is given by equation (5). For unemployment, columns (4)-(6) show the minimal response. Mean and maximum responses are calculated over three years. Robust standard errors are reported in parentheses. $*, * *, * * *$ indicate statistical significance at 10,5 , and 1 percent levels. 